\title{
EVALUATION THE EFFECT OF SILDENAFIL CITRATE (SC OR VIAGRA) ON SENILE ALBINO RAT TESTIS (HISTOLOGICAL AND BIOCHEMICAL STUDY)
}

Ezz-Eldin E-Abdalla*, Zienab M. Gebaly**, Abd-Elghany A.Moustafa*, Ibrahim M. Amr*

Histology Department, Faculty of Medicine (Damietta)* \&Histology Department, Faculty of Medicine for girls (Cairo) ** Al-Azhar University

\begin{abstract}
Sildenafil citrate (SC or Viagra) is an oral medication widely used to treat erectile dysfunction and maintains a sufficient erection for satisfactory sexual performance. The side effects of sildenafil citrate have been reported.
\end{abstract}

Aim of the work: The present study was designed to investigate the effect of sildenafil citrate in the therapeutic dose in different regimes.

Materials and methods: This study included forty senile male albino rats divided into four equal groups. Group (A) was used as a control group (did not receive any treatment). Group (B) receive the therapeutic dose of Viagra (1.5 $\mathrm{mg}$ suspended in $1.5 \mathrm{ml}$ distilled water) orally using a gastric gavage as daily dose for one week. Group (C) received the therapeutic dose of Viagra 3 times / week for two weeks. Group (D) received the therapeutic dose of Viagra each week for 4 weeks. Half of the treated rats of the different groups were sacrificed, other half were sacrificed after two weeks from the last dose as recovery groups (RB, RC and RD). The testes were dissected and blocked in paraffin. Hematoxylin and Eosin (HX\&E) and Periodic acid Schiff stain (PAS) were applied and serum testosterone levels in the different groups were evaluated.

Results: The present study showed that the therapeutic dose of sildenafil caused several histological findings in the germinal epithelial of the rat testes including degeneration, detachment of the spermatogenic cells especially the primary spermatocytes with addition thickening of the basement membranes of the seminiferous tubules and increased interstitial Leydig cells. The serum testosterone of the treated rats showed increased level of testosterone especially in group D. The recovery rats showed relative improvement of parameter toward normal.

Conclusion: Sildenafil produce morphological and histological alterations in the testes.

Key words: Sildenafil, Testes, Senile Albino rats and Testosterone.

\section{INTRODUCTION}

Sildenafil citrate (Viagra), have become one of the most prescribed and abused pharmaceutical (Feldman et al., 1994).
Sildenafil citrate is a water soluble citrate salt that was firstly synthesized by Pfizer in United Kingdom to treat hypertension 
and angina pectoris. Interestingly, this drug exhibited a different pharmacological effect, a marked penile erection, and became the first-line treatment option to erectile dysfunction (Kalsi and Kell, 2004; Uthayathas et al., 2007).

Sildenafil citrate is the first oral agent to be introduced for the management of erectile dysfunction (ED). When administered before sexual activity, it produces reliable efficacy, good tolerability and rapid absorption that yields prompt onset of action; it has a plasma half-life that produces an appropriate duration of action while avoiding accumulation on repeated once-daily use

(Boolell et al., 1996; Kloner and Zusman, 1999).

The drug has been reported to be effective only in about $78 \%$ of patients with psychogenic ED (McMahon et al., 2000). It is likely that performance anxiety and sympathetic overtone are the cause of this unresponsiveness to sildenafil citrate during awakening, though data supporting this assumption are lacking (Rosen, 2001). The drug has been found to be effective and well tolerated in men with mild to moderate erectile dysfunction of no clinically identifiable organic cause (Eardley, 2001).

Sildenafil citrate (SC) is a cyclic nucleotide phosphodiesterase-5 (PDE5) inhibitor and it causes intracellular accumulation of cyclic guanosine monophosphate (Corbin and Francis, 1999; Abbott et al., 2004) through action of the endogenous nitric oxide-cyclic guanosine monophosphate (NO-cGMP) pathway. Also it acts as corpus cavernosum vasodilator, increased blood flow and enhanced erectile function in human (Burnett, 1995; Michel, 2006) and murine (Mizusawa et al., 2001). It was revealed that the SC can act by relaxing the arterial wall due to the presence of PDE5 in the arterial wall (Uthayathas $\boldsymbol{e t}$ al., 2007).

Pfizer (1998) stated that the side effects of Sildenafil are mostly mild to moderate. They usually go away after a few hours. Some of these are more likely to happen with higher doses.

Sildenafil had provoked tubular and interstitial histological alterations of the seminiferous tubules, increased Leydig cells cellularity, tubular degeneration, which finally might lead to complete arrest of spermatogenesis, but SC has no effect on epididymis histology (Jarrar, 2011).

The drug mechanism could be involved in the activation of the steroidogenic pathway and testosterone secretion, as recently PDE5 was identified in Leydig cells (Scipioni et al., 2005).

\section{MARTIAL AND METHODS}

Forty senile male Albino rats were used in this study. Their body weight ranged between 250-300 grams. The experimental animals were divided into 
four equal groups. Group (A) was used as a control group (did not receive any treatment). Group (B) received the therapeutic dose of Viagra $(1.5 \mathrm{mg}$ suspended in $1.5 \mathrm{ml}$ distilled water) orally using a gastric gavage as daily dose for one week. Group (C) received the therapeutic dose of Viagra 3 times / week for two weeks. Group (D) received the therapeutic dose of Viagra each week for 4 weeks. Half of the treated rats of the different groups were sacrificed, other half were sacrificed after two weeks from the last dose as recovery groups ( $\mathrm{RB}, \mathrm{RC}$ and $\mathrm{RD})$. The testes were dissected,then fixed in Bouin's solution and processed for paraffin sections of 6 micron thickness.

\section{Sildenafil citrate (SC or Viagra)}

The dosage range for human is 25 100 mg/day, orally, according to the severity of the condition. The average dose prescribed for human $(62.5 \mathrm{mg} /$ day $)$ was converted to equivalent dose for rat according to Paget and Barnes (1964) .The rat dose was calculated as 5.625 $\mathrm{mg} / \mathrm{kg}$ body weight. Thus, a rat weighing 250-300 g received a daily dose of $1.5 \mathrm{mg}$ suspended in $1.5 \mathrm{ml}$ distilled water orally using a gastric tube of a suitable size.

Each 100mg tablet of sildenafil citrate dissolved in 100 cubic $\mathrm{cm}$ of D.W., so each 1 cubic $\mathrm{cm}$ contained $1 \mathrm{mg}$ of the drug. So every $250 \mathrm{gm}$ of the rat received $1.5 \mathrm{mg}$ of the drug $=1.5$ cubic $\mathrm{cm}$ of the drug solution.

\section{Parameters of the study:}

\section{A) Microscopic study:}

Sections from each group were stained with Hematoxylin and eosin (HX\&E) (Drury and Wallington, 1980) and Periodic acid Schiff stain (PAS) with hematoxylin counterstaining (Pearse, 1977).

\section{B) Biochemical tests:}

Collection of rats serum was taken for estimating the testosterone hormone .Data were analyzed with Mann-Whitney test to compare the testosterone levels (ng/ml)between controls, the groups submitted to Sildenafil treatment and the recovery groups (Zar, 1996).

\section{C) Image analyzer:}

Paraffin sections were examined using Licua Qwin 500 image analyzer computer system, England. Image analyzer was used to measure the thickness of the basement membrane of seminiferous tubules and measure the mean optical density (MOD) of PAS through quantifiable integrated optical density using 10x eyepiece and 40x objective lens .The measurement were carried out on 10 fields for each specimen to determine thickness of the basement membranes and (MOD) PAS with standard measuring frame.

\section{D) Statistically evaluation:}

All of the statistical analyses were performed by SPSS 12 (SPSS Inc., USA). Descriptive statistics are shown as 
arithmetic mean + SD .After the tests of normality, the differences between the control group, the treated groups and recovery groups were investigated with analysis of T-test and $\mathrm{P}$ is significant at $<$ 0.05 (Altman, 1991).

\section{RESULTS}

\section{A) Histological results}

\section{Control group (A):}

Microscopic examination of testicular sections of this control group revealed rounded seminiferous tubules with regular outlines. They were lined by layers of germinal epithelium at different stages of spermatogenesis. The flagella of mature sperms were seen filling the lumens of the seminiferous tubules. The interstitial spaces in-between the tubules contained interstitial cells of Leydig. The lining epithelium consisted of Sertoli cells and germinal cells. The germinal epithelium consisted of spermatogonia cells resting on the basement membrane, large rounded 1ry spermatocytes with large vesicular nuclei, also spermatid could be recognized by its darkly stained rounded nuclei and its position towards the lumen, while spermatozoa appeared elongated in shape with pointed end (Figs.1\&2) . PAS stained sections showed normal distribution of PAS+ve materials in the basement membranes of the seminiferous tubules and in the different spermatogenic layers (Fig.3).

\section{Group B:}

Microscopic examination of testicular sections of group B revealed germinal epithelium at different stages of spermatogenesis with decreased thickness of germ cells layers and detached germ cells, also increased number of Leydig cells and increased width of the interstitial spaces in-between the tubules (Figs.4\&5).
PAS stained sections showed increased stain affinity in the basement membrane of the seminiferous tubules (Fig.6).

Group C:

Microscopic examination of testicular sections of group $\mathrm{C}$ revealed impaired spermatogenesis, detached germ cell (Notice: some cells with pyknotic nuclei) with decreased of thickness of germ cell layers, but focal spermatogensis noted as some spermatic were noticed in the sections with widened interstitial tissue, thickened basement membrane, increased number of Leydig cells (Figs. 7,8\&9).

PAS stained sections showed increased stain affinity in the basement membranes of the seminiferous tubules (Fig.10).

Group D:

Microscopic examination of testicular sections of group D showed alterations of some tubules in the form of arrested spermatogenesis at level of 1ry spermatocytes, detached and reduction in number of layers of germinal epithelium cells. Signs of necrosis of seminiferous tubules appeared in form of, some cells of 1ry spermatocytes showed with pyknotic or karyolytic nuclei with shrinked cells. Notice dilated interstitial tissues with deposition of acidophilic materials with marked congested and dilated blood vessels with increased number of Leydig cells (Figs.11,12\&13).

In PAS stained sections showed intensed of PAS+ve materials in the basement membranes of the somniferous tubules (Fig.14).

\section{Recovery group (RB, RC and RD):}

Microscopic examination of testicular sections of recovery groups revealed the changes in testicular structure reversed after stoppage of the drug (Fig. $15,16,17,18,19 \& 20)$. 
The Egyptian Journal of Hospital Medicine (2012) Vol. 49; 911- 932

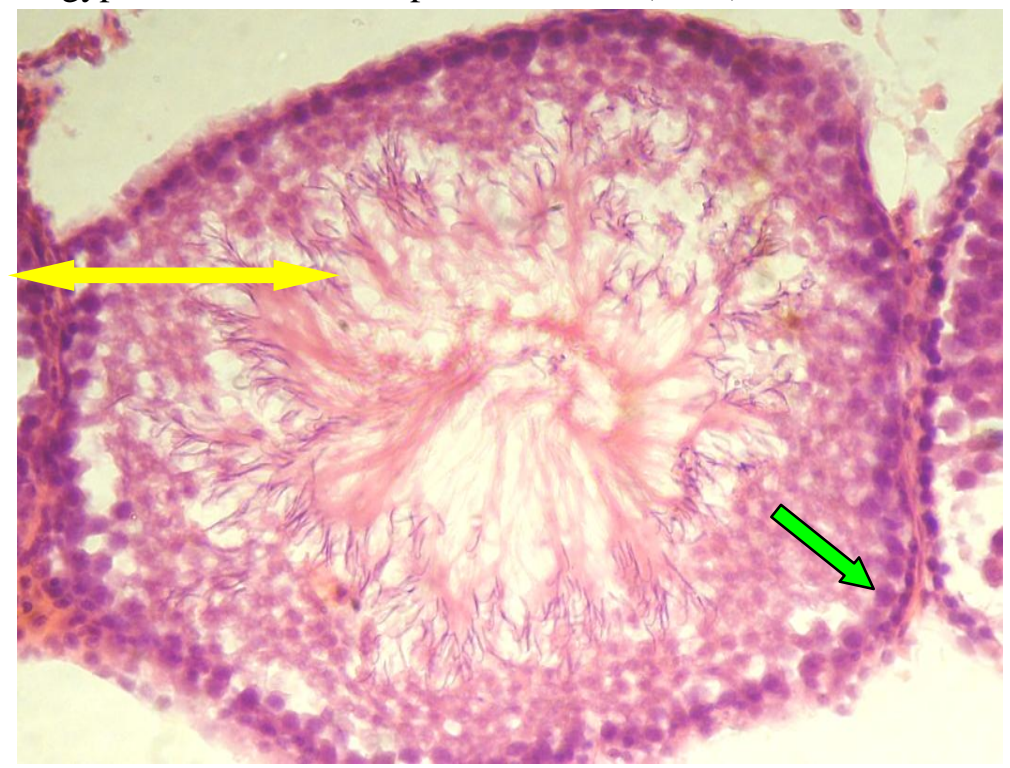

Fig. (1): Photomicrograph of control rat testis (group A) showing one seminiferous tubule with its normal structure (spermatogonia, 1ry spermatocytes and sperms by means active spermatogenesis (yellow arrow)) and normal interstitial tissue (green arrow) (H x \& E x400).

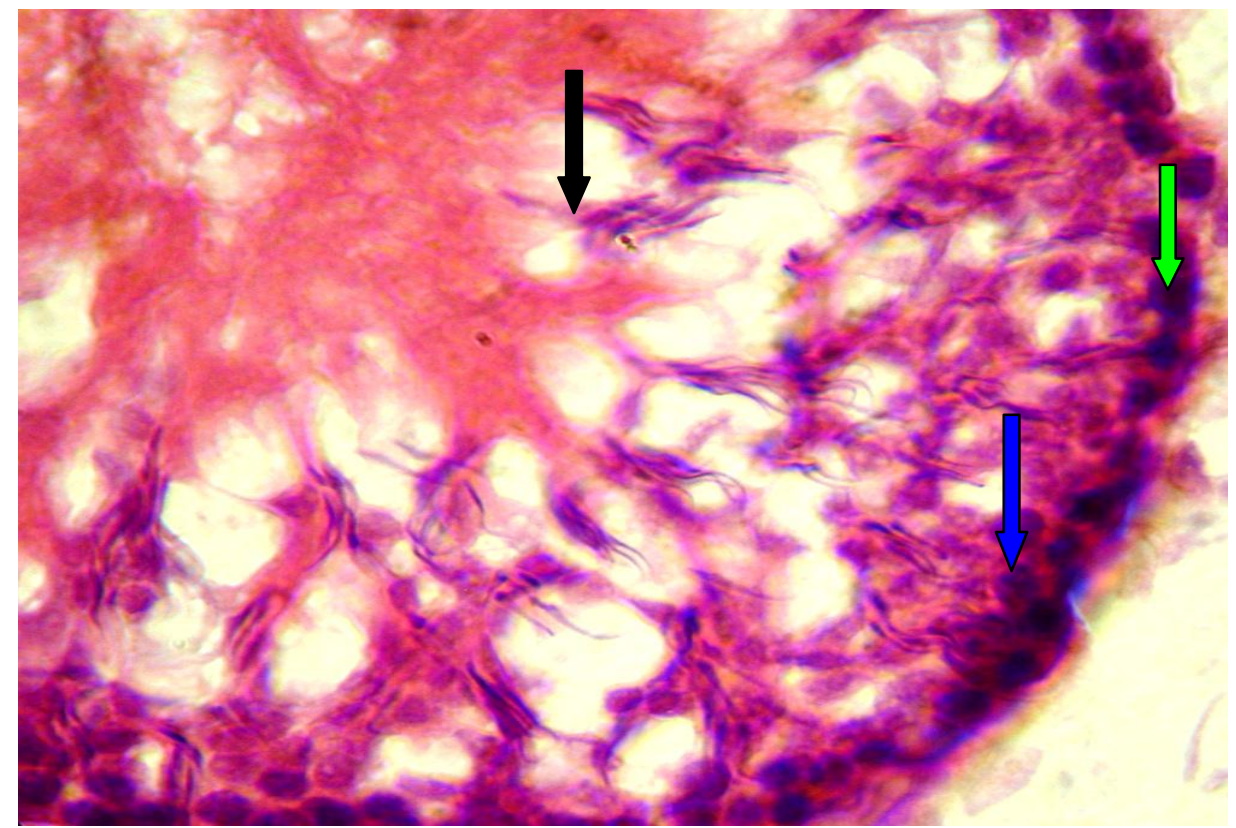

Fig. (2): Photomicrograph of control rat testis showing spermatogonia (green arrow), 1ry spermatocytes (blue arrow) and sperms (black arrow) (active spermatogenesis). ( $\mathrm{H} \mathrm{x} \& \mathrm{E}$ $\mathrm{x} 1000)$. 
Ezz-Eldin Abdalla et al

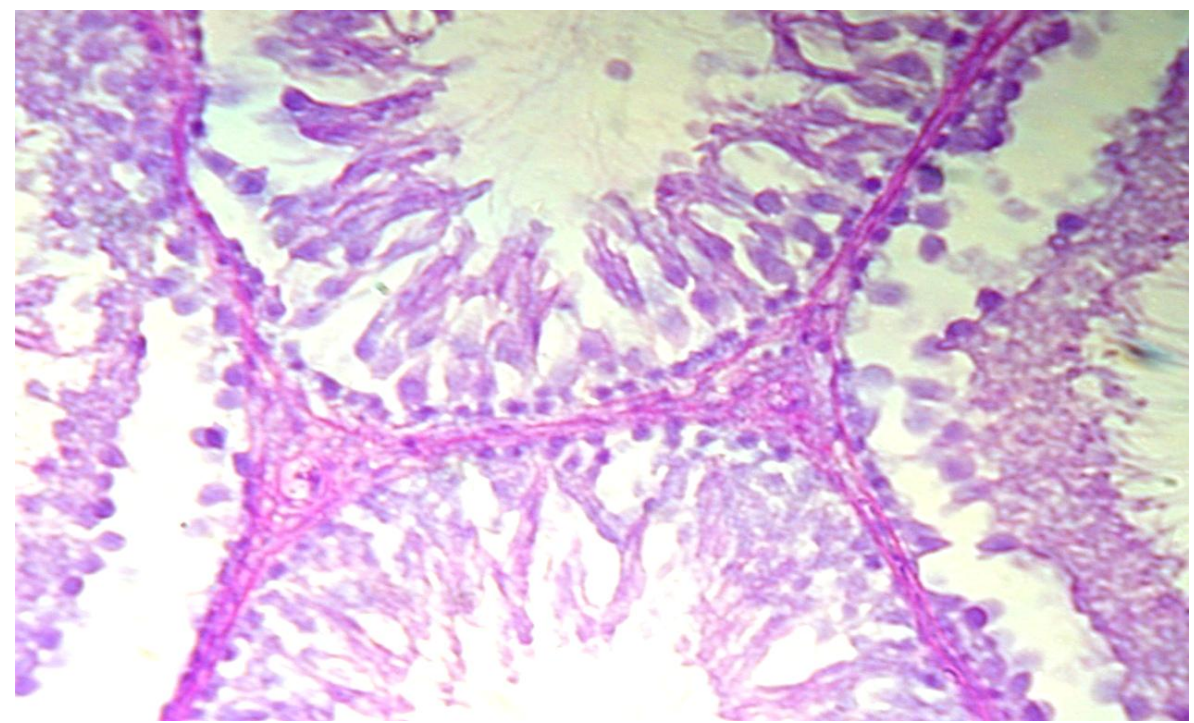

Fig. (3): Photomicrograph of the control rat testis showing normal distribution of PAS +ve materials in the basement membranes of seminiferous tubules (PAS reaction X 400).

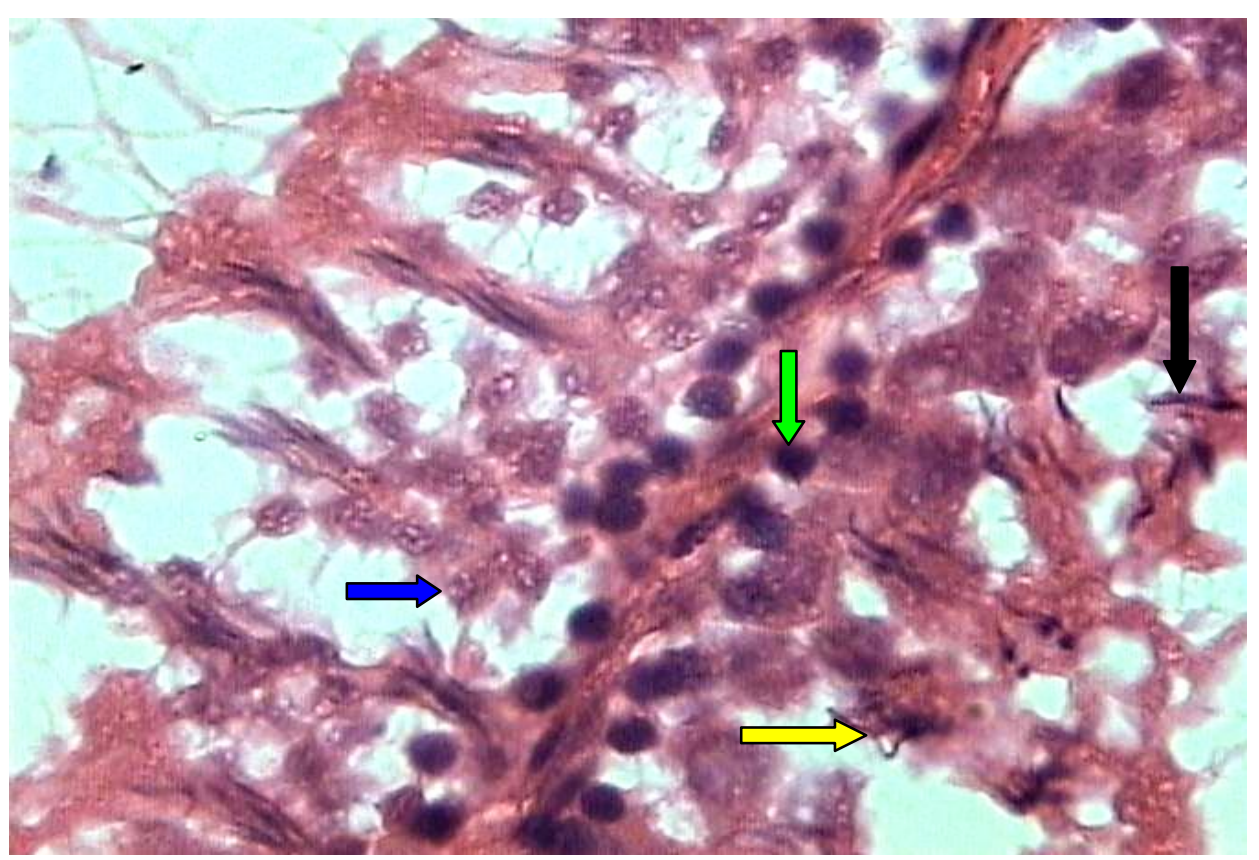

Fig. (4): Photomicrograph of group B rat testis showing spermatogonia (green arrow), 1ry spermatocytes (blue arrow) spermatid (yellow arrow) and sperms (black arrow) (H x \& E $\mathrm{x} 1000)$. 
EVALUATION THE EFFECT OF SILDENAFIL CITRATE...

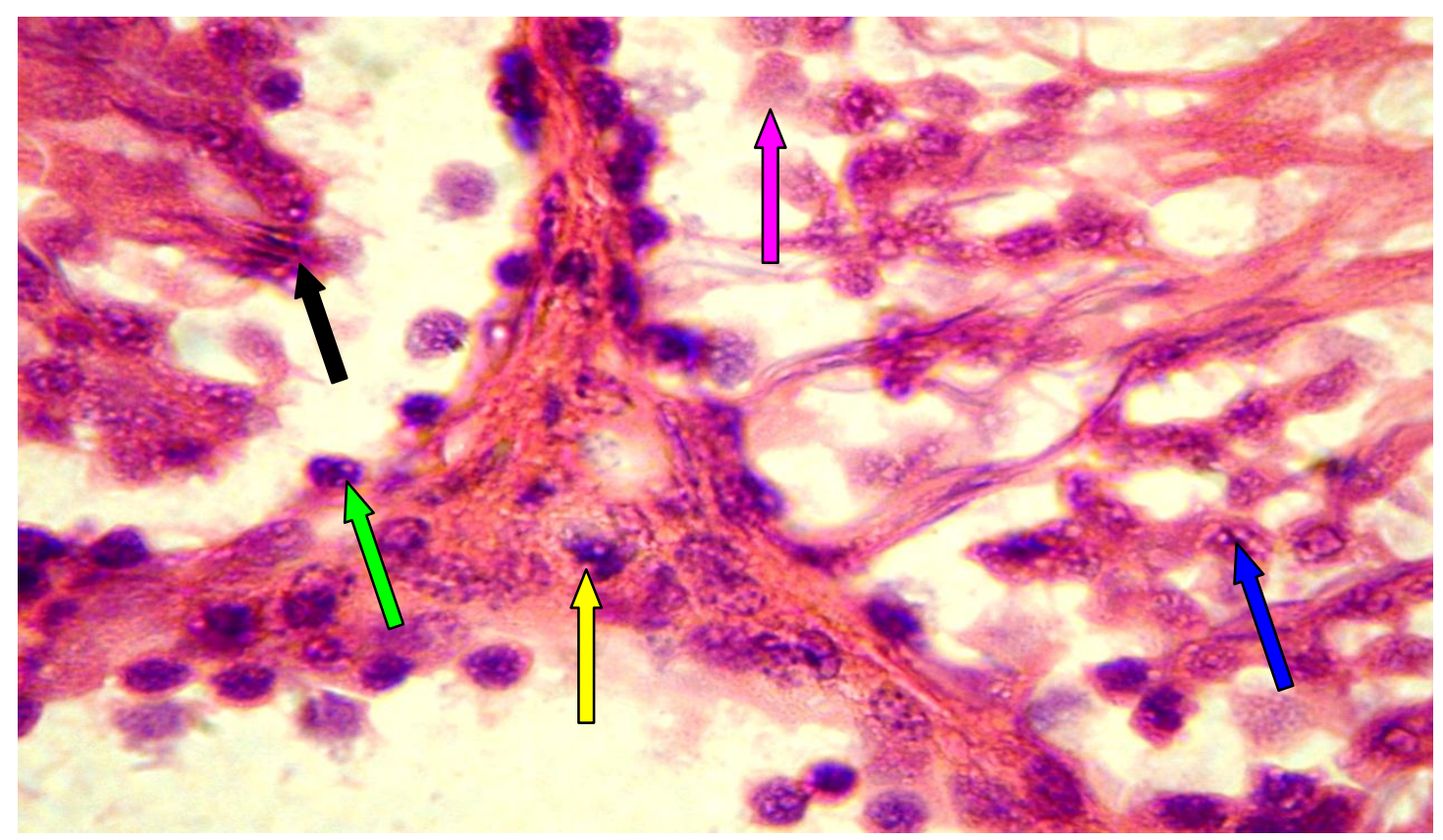

Fig. (5): Photomicrograph of group B rat testis showing spermatogonia (green arrow), 1ry spermatocytes (blue arrow) and sperms (black arrow) with decreased thickness of the germ cell layers and detached (pink arrow) cells(green arrow) and increased number of Leydig cells (yellow arrow) (H x \& E x1000).

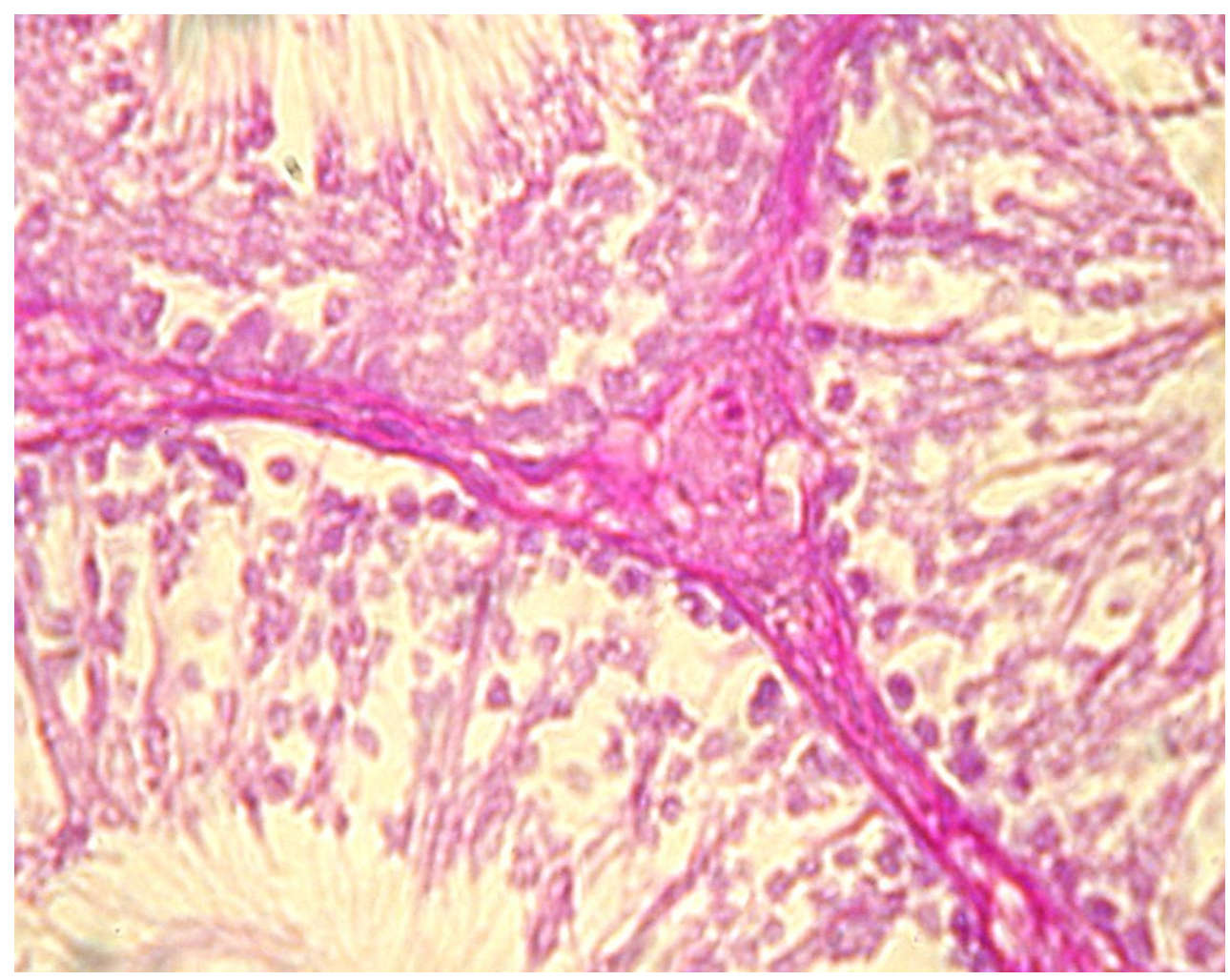

Fig. (6): Photomicrograph of group B rat testis showing increased PAS+ve materials in the basement membranes of seminiferous tubules (PAS reaction X 400). 


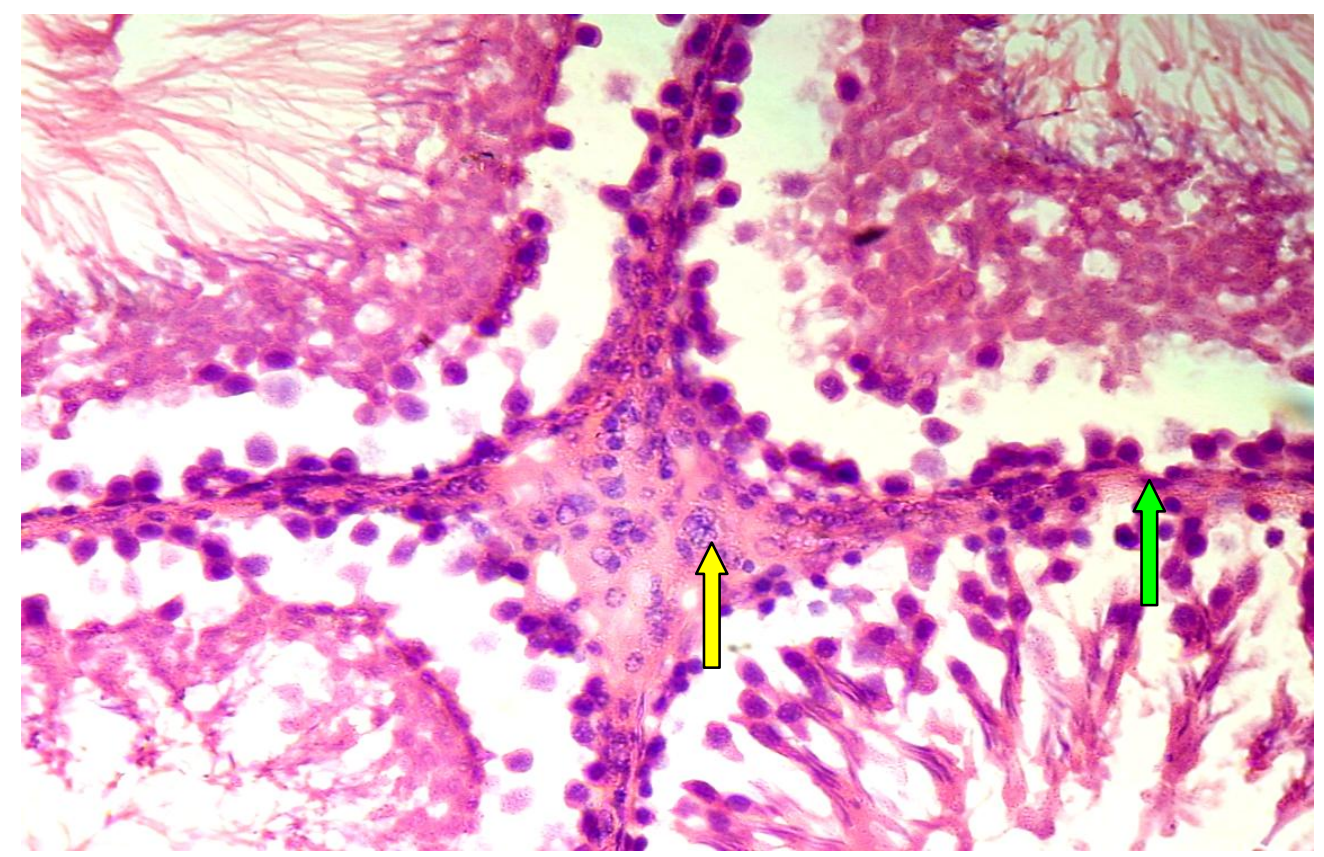

Fig. (7): Photomicrograph of group $\mathrm{C}$ rat testis showing impaired spermatogenesis and thickened basement membrane (green arrow) and increased number of Leydig cells (yellow arrow) (H x \& E x400).

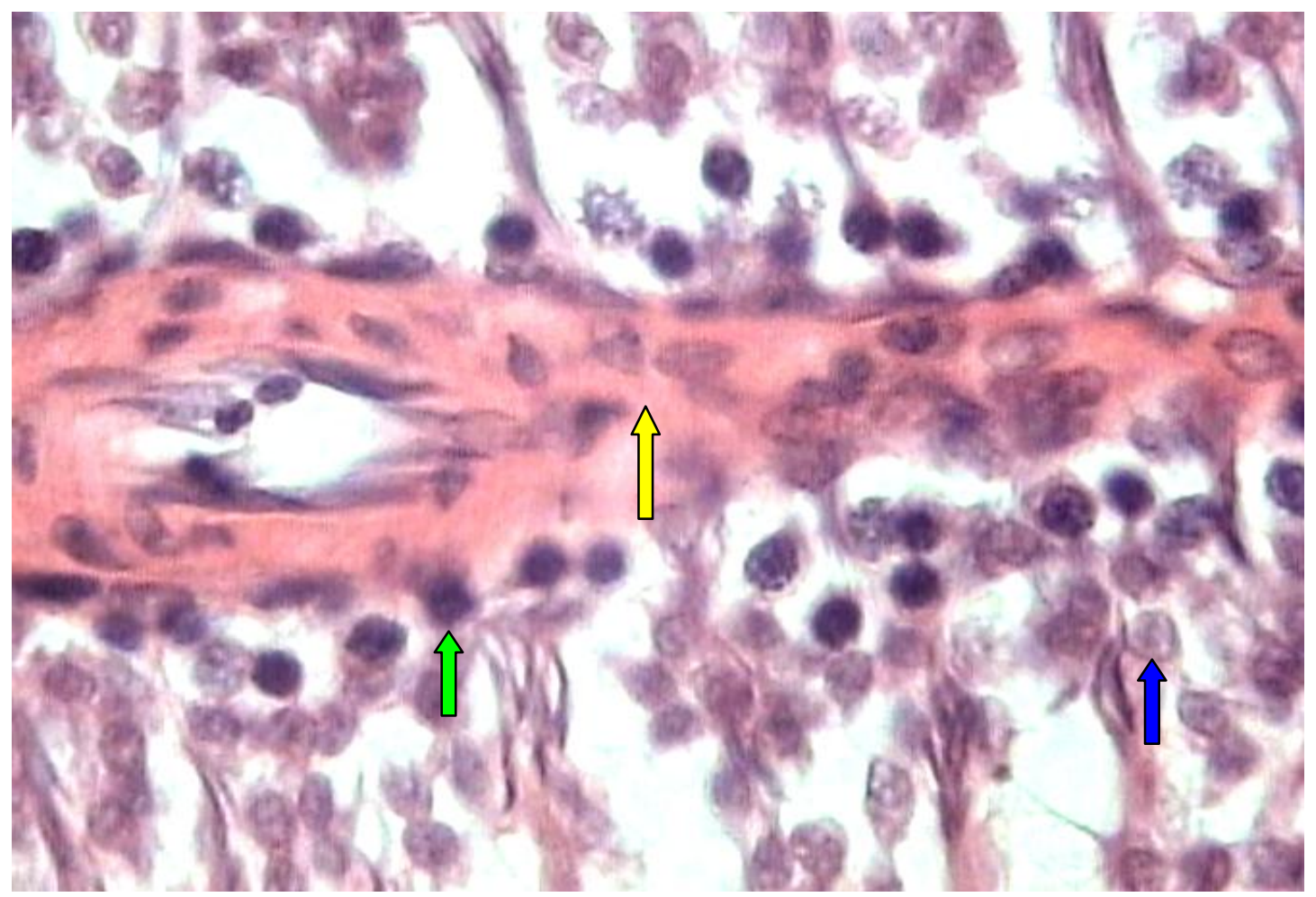

Fig. (8): Photomicrograph of group C rat testis showing spermatogonia (green arrow), active $1^{\text {ry }}$ spermatocytes (blue arrow), widened interstitial tissue with deposition of acidophilic material (yellow arrow) and decreased thickness of the germ cells layers (H x \& E x1000) . 


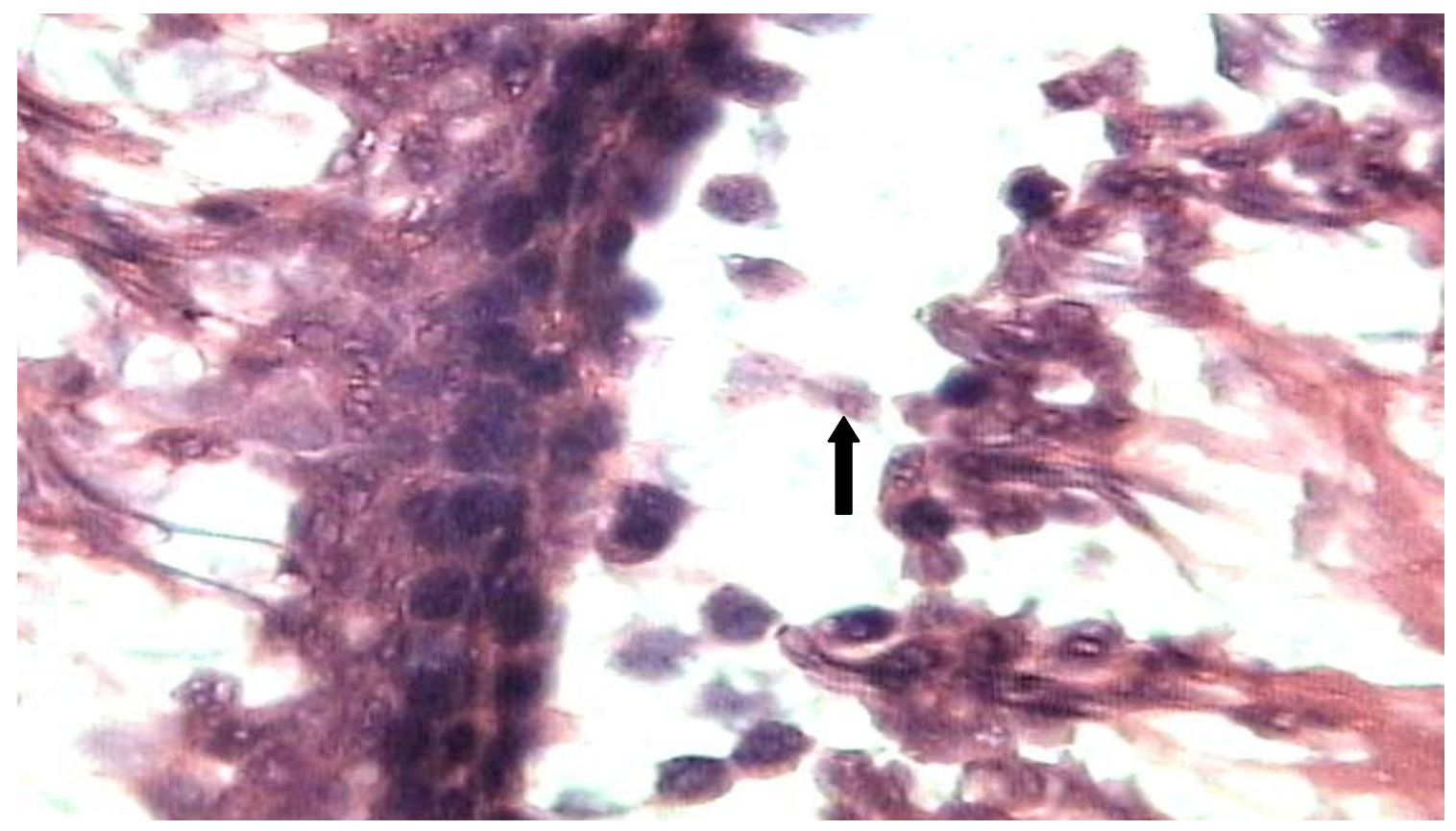

Fig. (9): Photomicrograph of group $\mathrm{C}$ rat testis showing impaired spermatogenesis and disruption of the epithelial lining of the tubules which appeared to be lined by few layers. Notice: some cells with pyknotic nuclei (black arrow) (Hx\&E x1000).

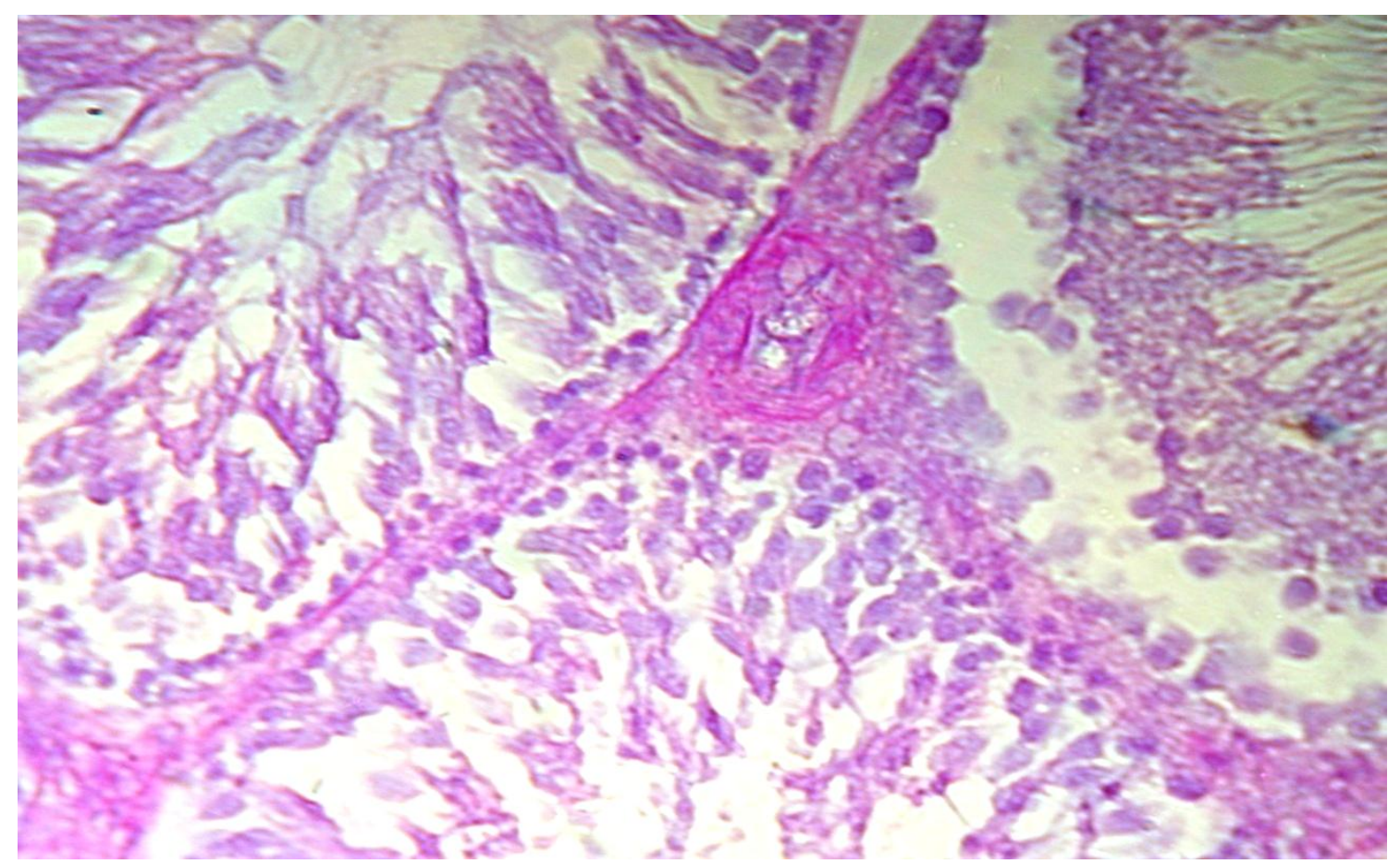

Fig. (10): Photomicrograph of group C rat testis showing increase of PAS +ve material in the basement membranes of seminiferous tubules (PAS reaction X 400). 


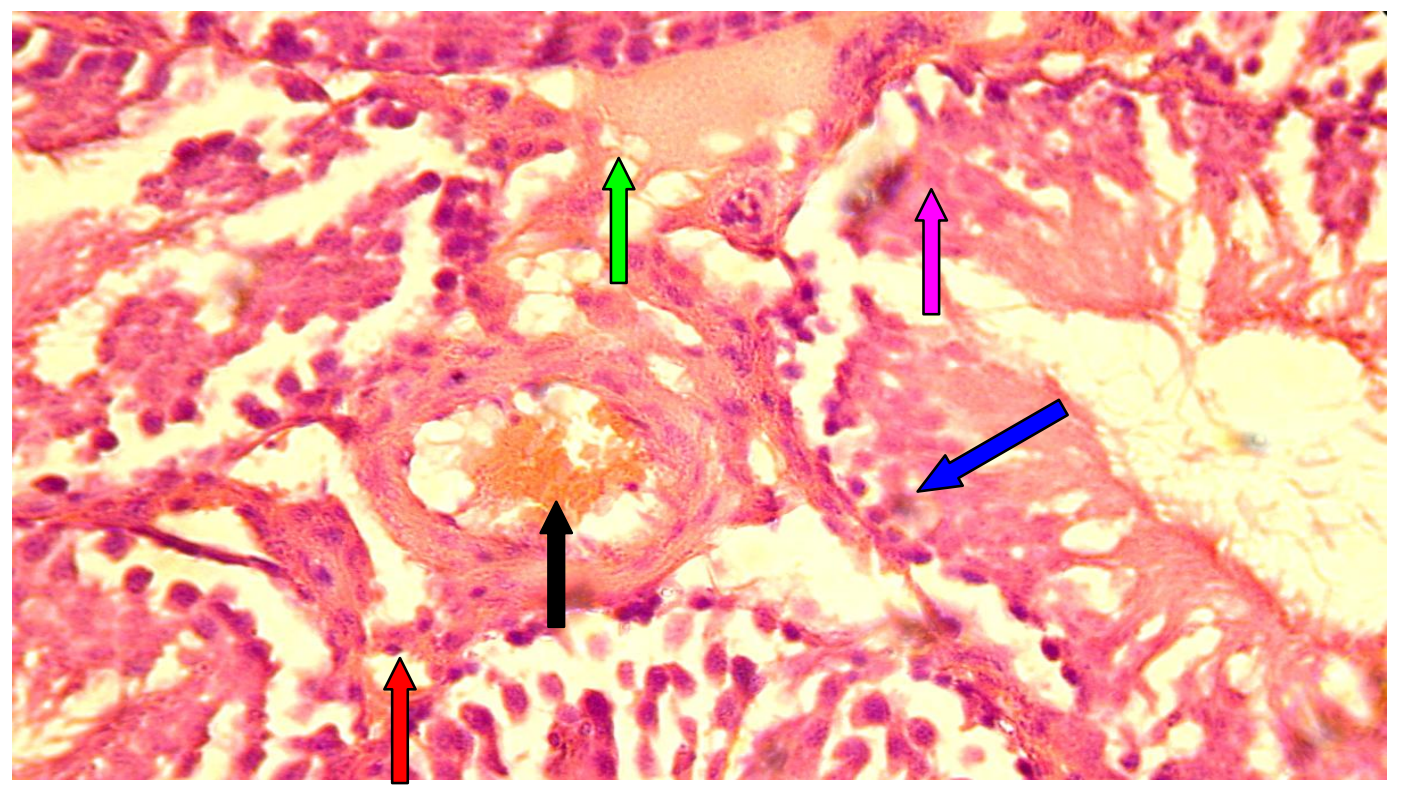

Fig.(11): Photomicrograph of group D rat testis showing arrested spermatogenesis at level of 1ry spermatocytes (blue arrow), detached germ cells (pink arrow), necrosis of seminiferous tubules, widened interstitial tissue with deposition of acidophilic materials (green arrow) and congested and dilated blood vessel (black arrow) (Hx\&E X 400).

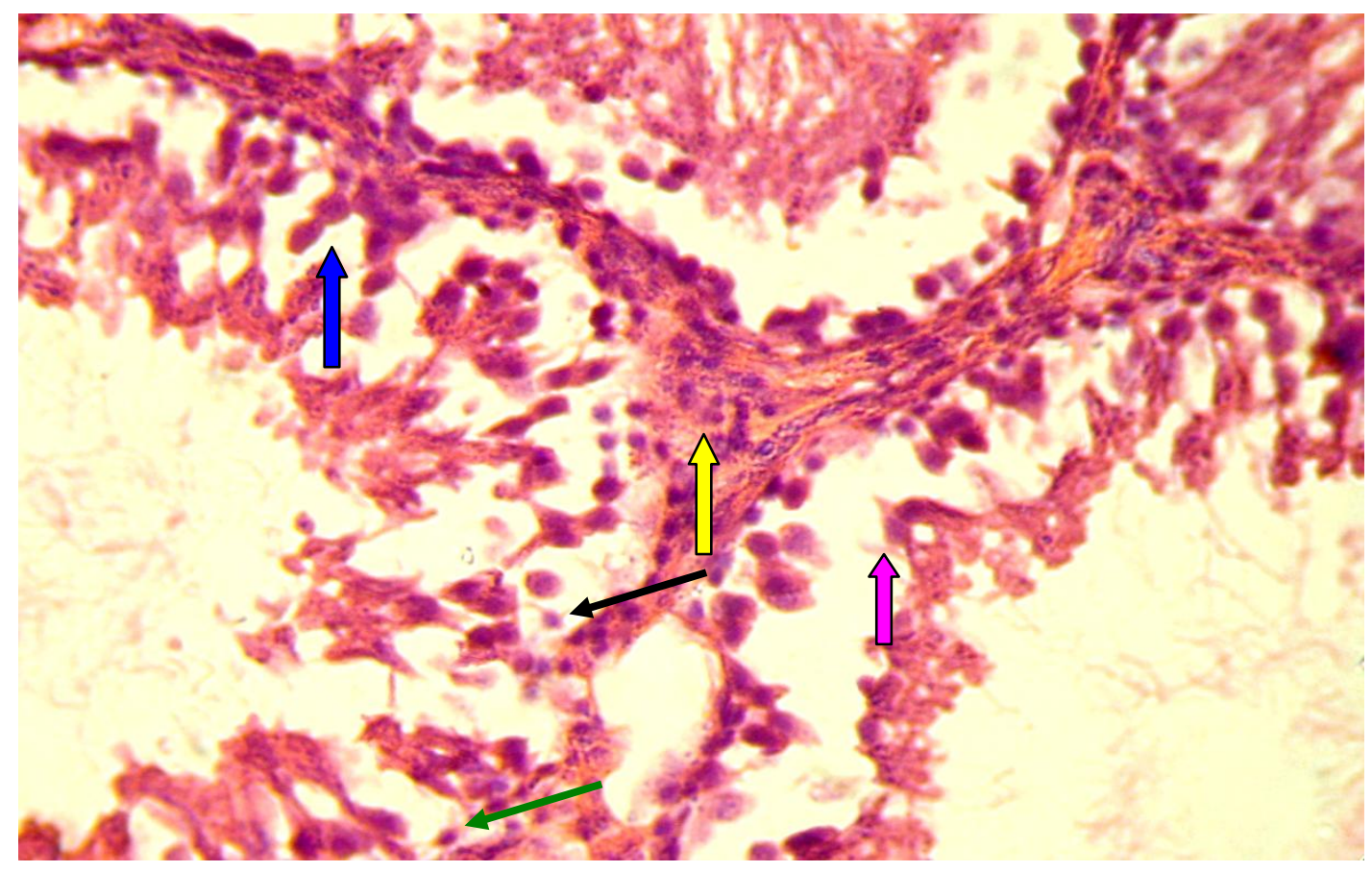

Fig. (12): Photomicrograph of group D rat testis showing arrested spermatogenesis at level of 1ry spermatocytes (blue arrow), disruption epithelial lining of some tubules which appeared lined by few layers (pink arrow) with increased number of Leydig cells (yellow arrow). Notice: some cells with pyknotic nuclei (green arrow), other cells are shrinked (black arrow) (Hx\&EX400). 


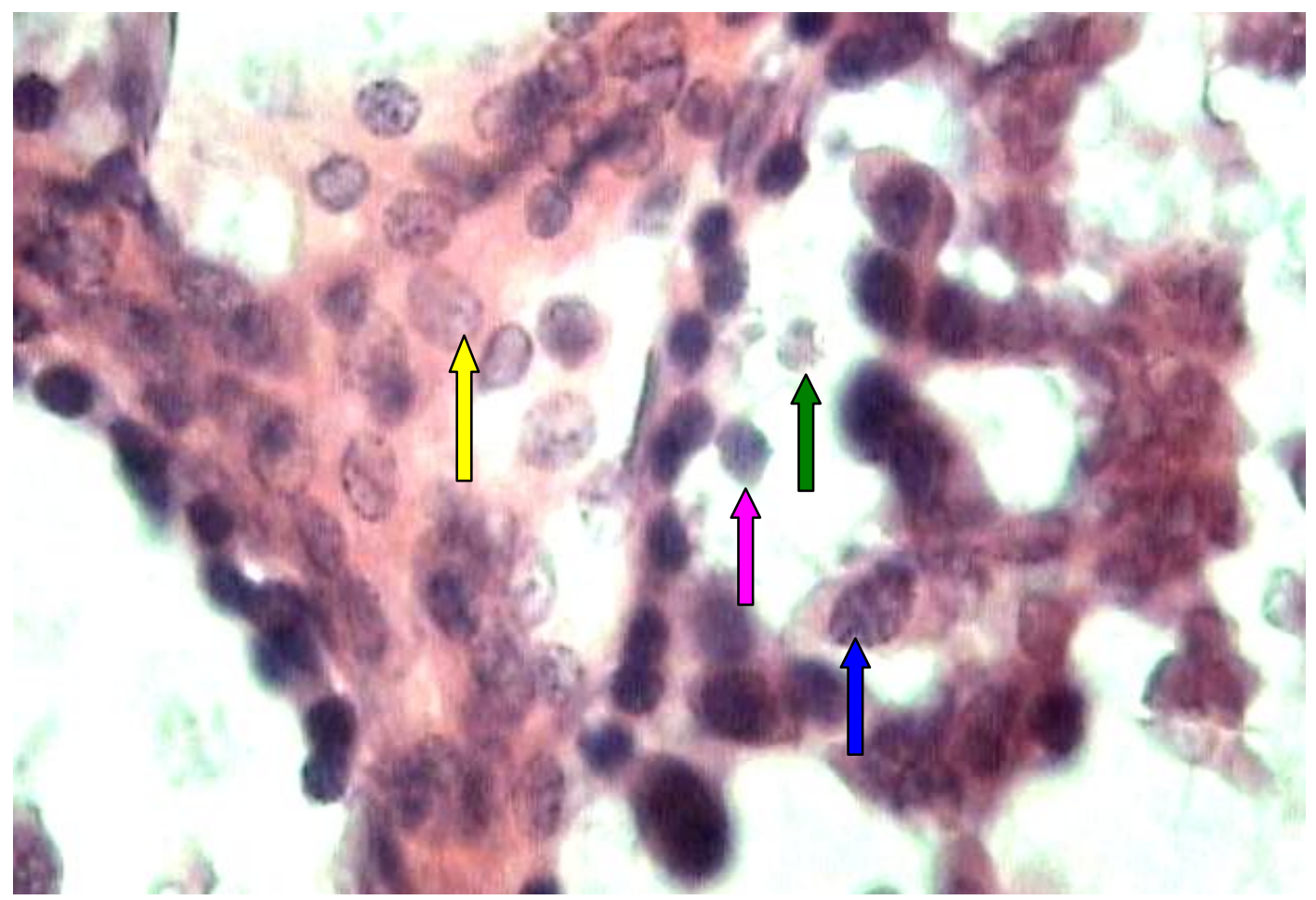

Fig. (13): Photomicrograph of group D rat testis showing arrested spermatogenesis at the level of $1^{\text {ry }}$ spermatocytes (blue arrow) with detached germ cells and increased Leydig cells (yellow arrow) in the interstitial tissues. Notice: some cells with pyknotic nuclei (pink arrow), other cells are shrinked (green arrow) (Hx\&E X 1000).

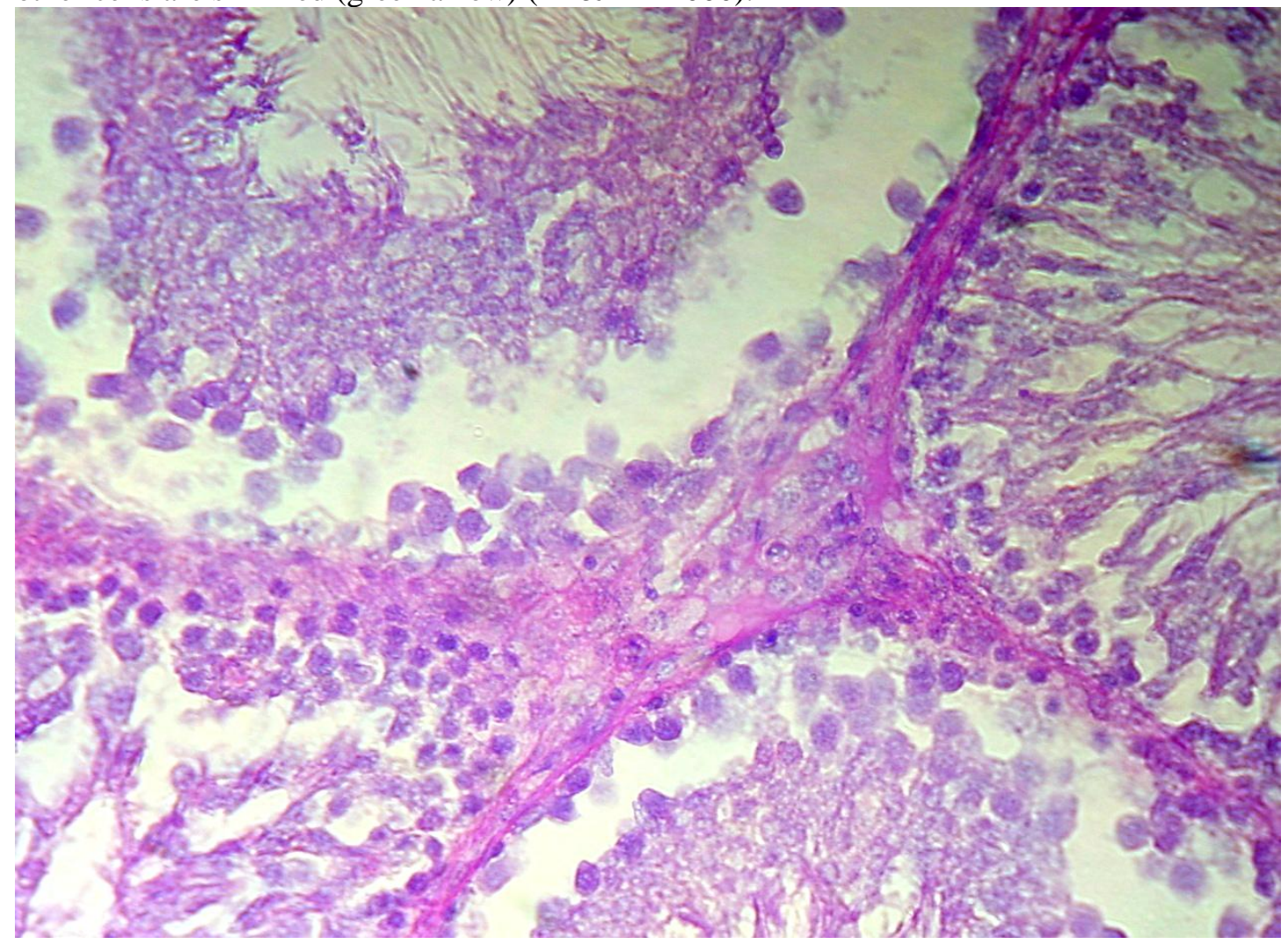

Fig. (14): Photomicrograph of group D rat testis showing intensed PAS +ve materials in the basement membranes of seminiferous tubules (PAS reaction X 400). 


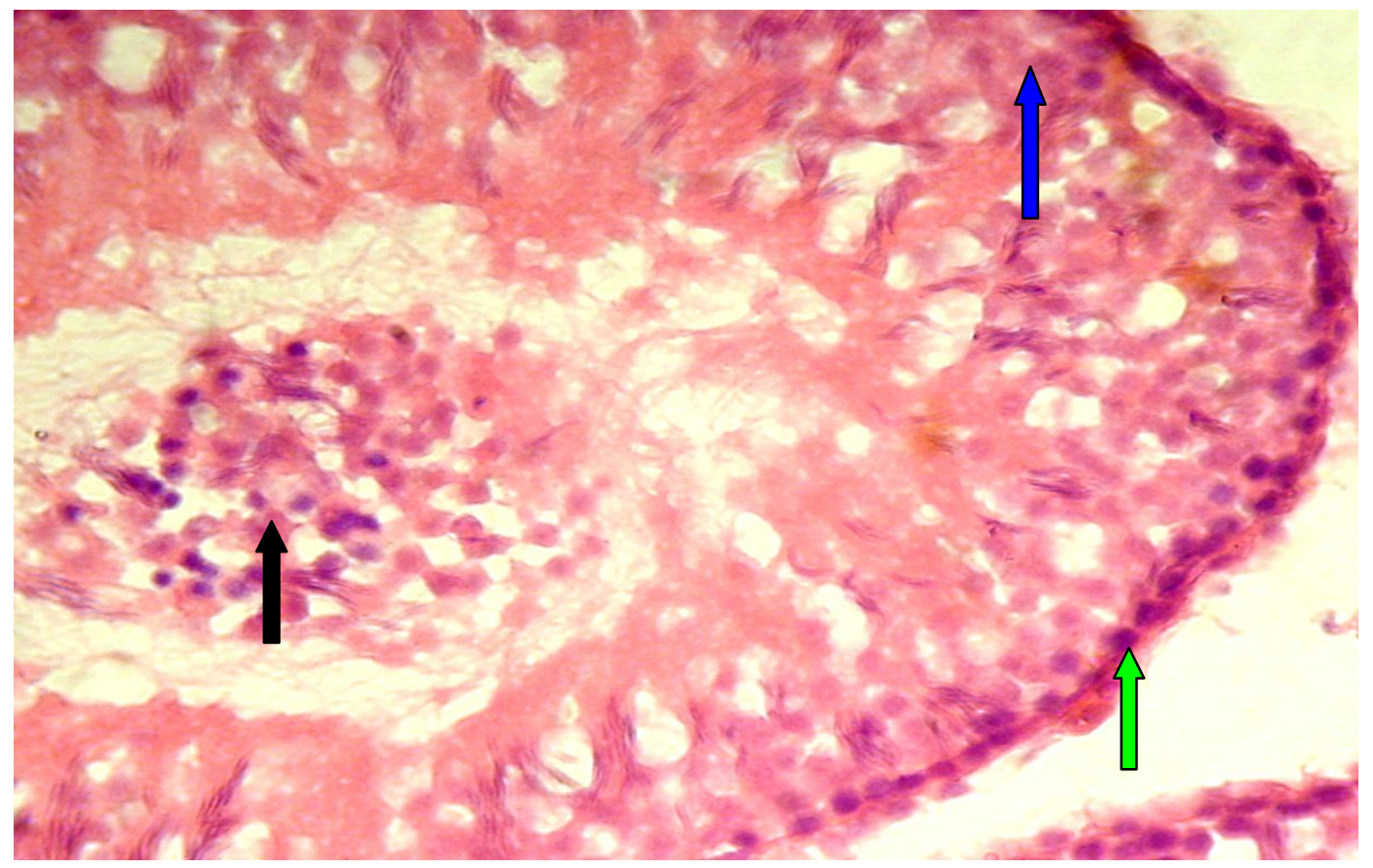

Fig. (15): Photomicrograph of recovery of group B rat testis showing spermatogonia (green arrow), $1^{\text {ry }}$ spermatocytes (blue arrow) and sperms (black arrow) with somewhat normal appearance of the seminiferous tubule (H x \& E x 400).

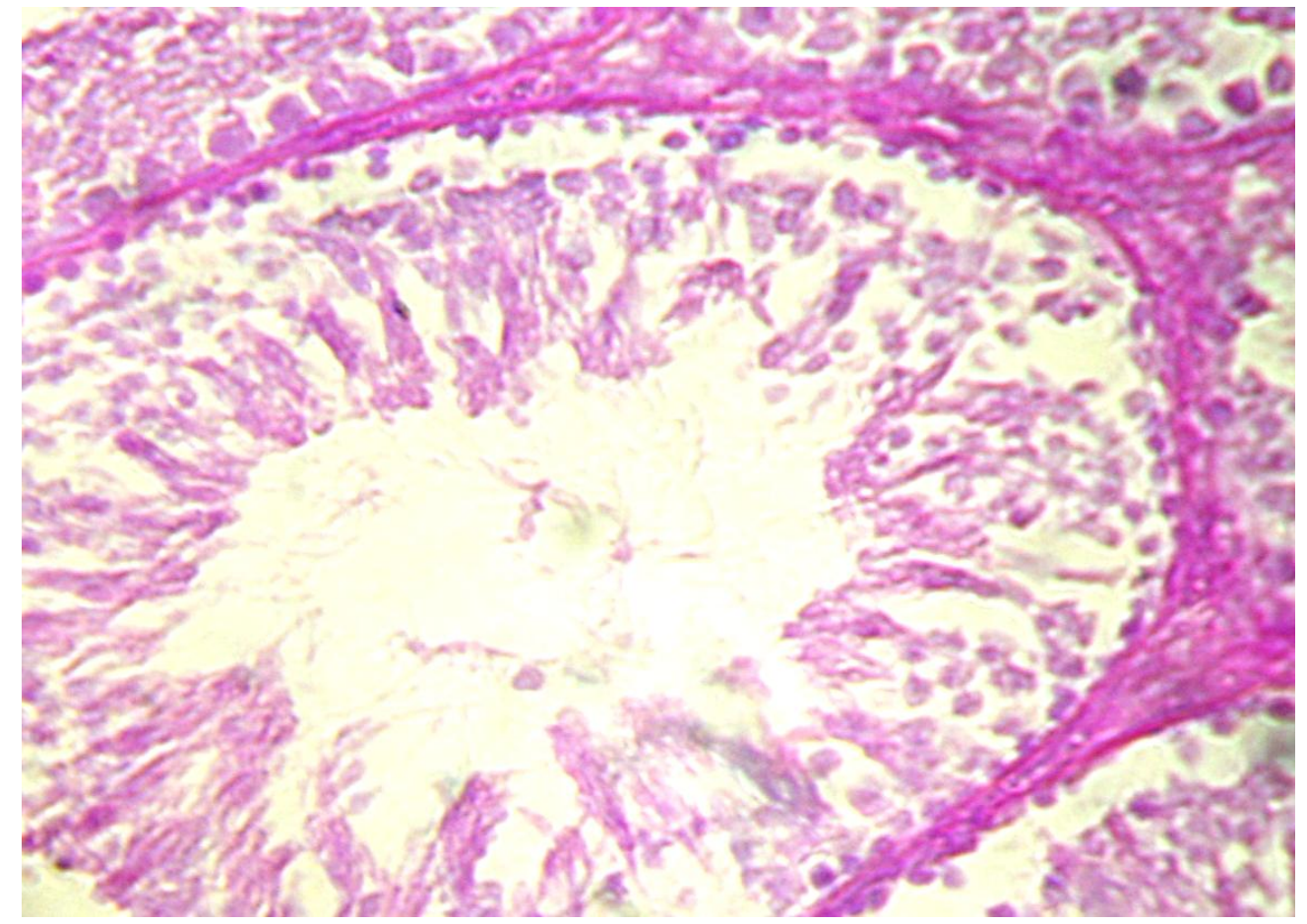

Fig. (16): Photomicrograph of recovery group B rat testis showing mild decrease of PAS +ve materials in the basement membranes of seminiferous tubules and in cells of spermatogenic layers (PAS reaction X 400). 


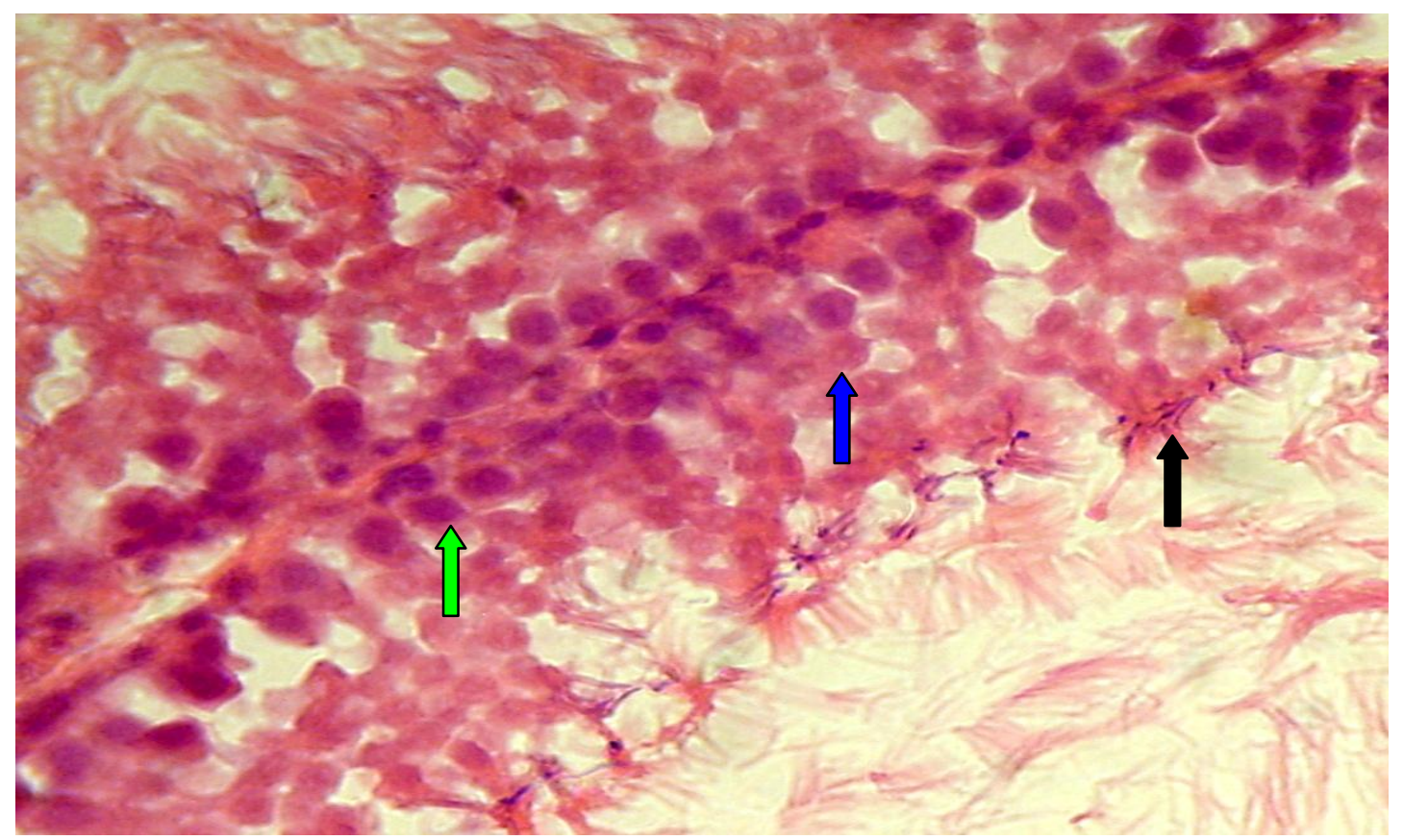

Fig. (17): Photomicrograph of recovery group $\mathrm{C}$ rat testis showing spermatogonia (green arrow), 1ry spermatocytes (blue arrow) and sperms (black arrow) more or less like the control group (H x \& E x400).

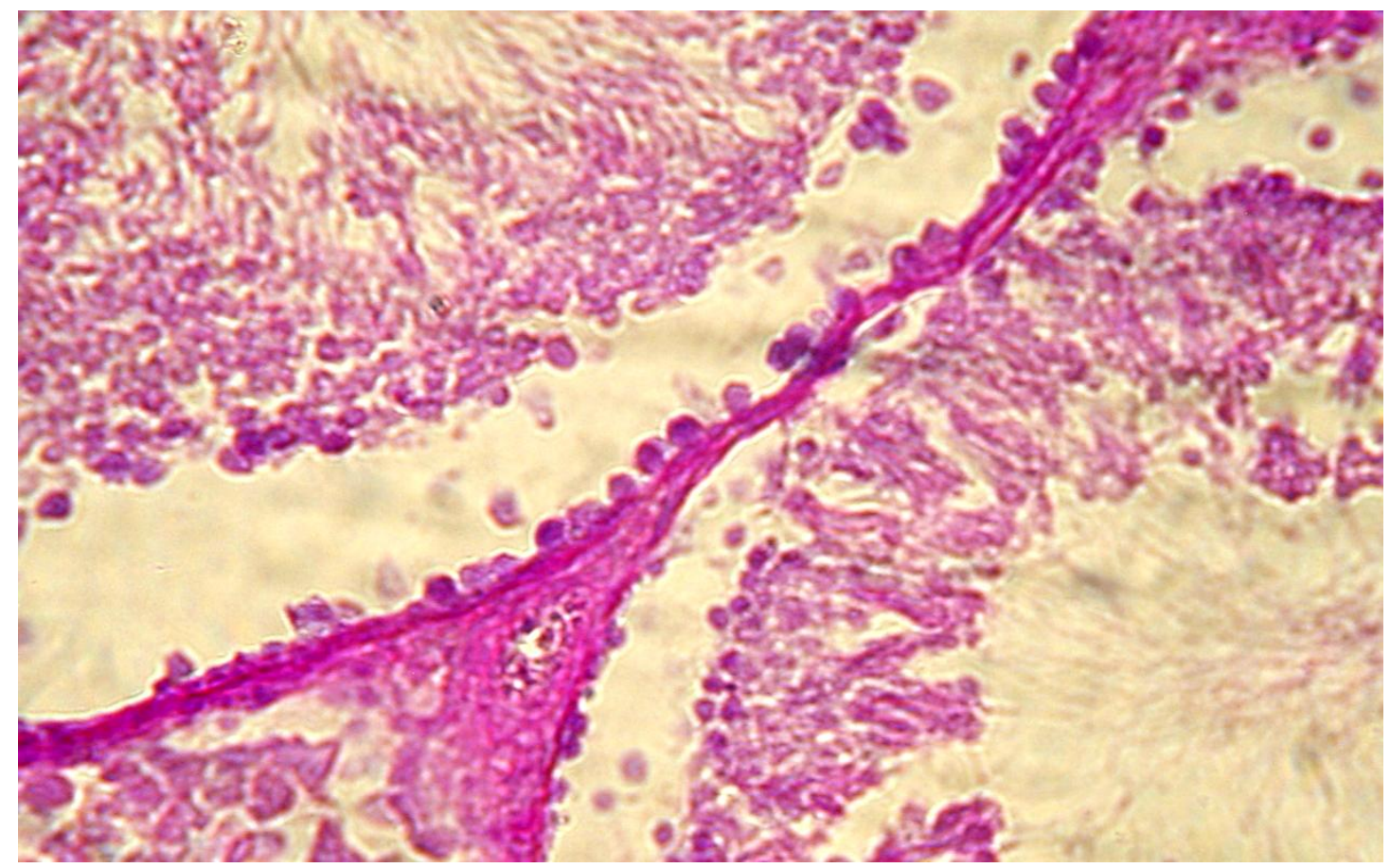

Fig. (18): Photomicrograph of recovery group $\mathrm{C}$ rat testis showing normal distribution of PAS +ve materials in the basement membranes of seminiferous tubules and in cells of spermatogenic layers (PAS reaction X 400). 


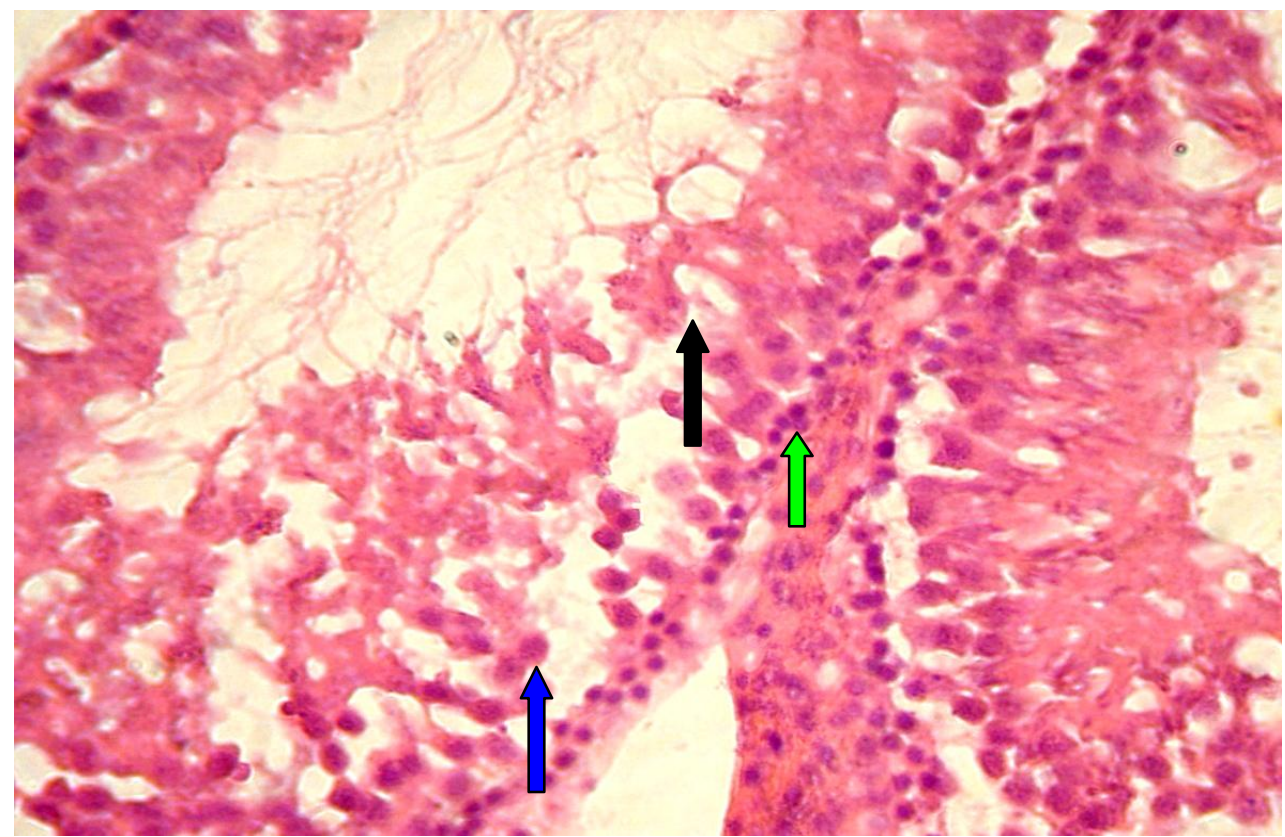

Fig. (19): Photomicrograph of recovery group D rat testis showing spermatogonia (green arrow), $1^{\text {ry }}$ spermatocytes (blue arrow) and spermatid (black arrow) more or less as control group. (H x \& E x400).

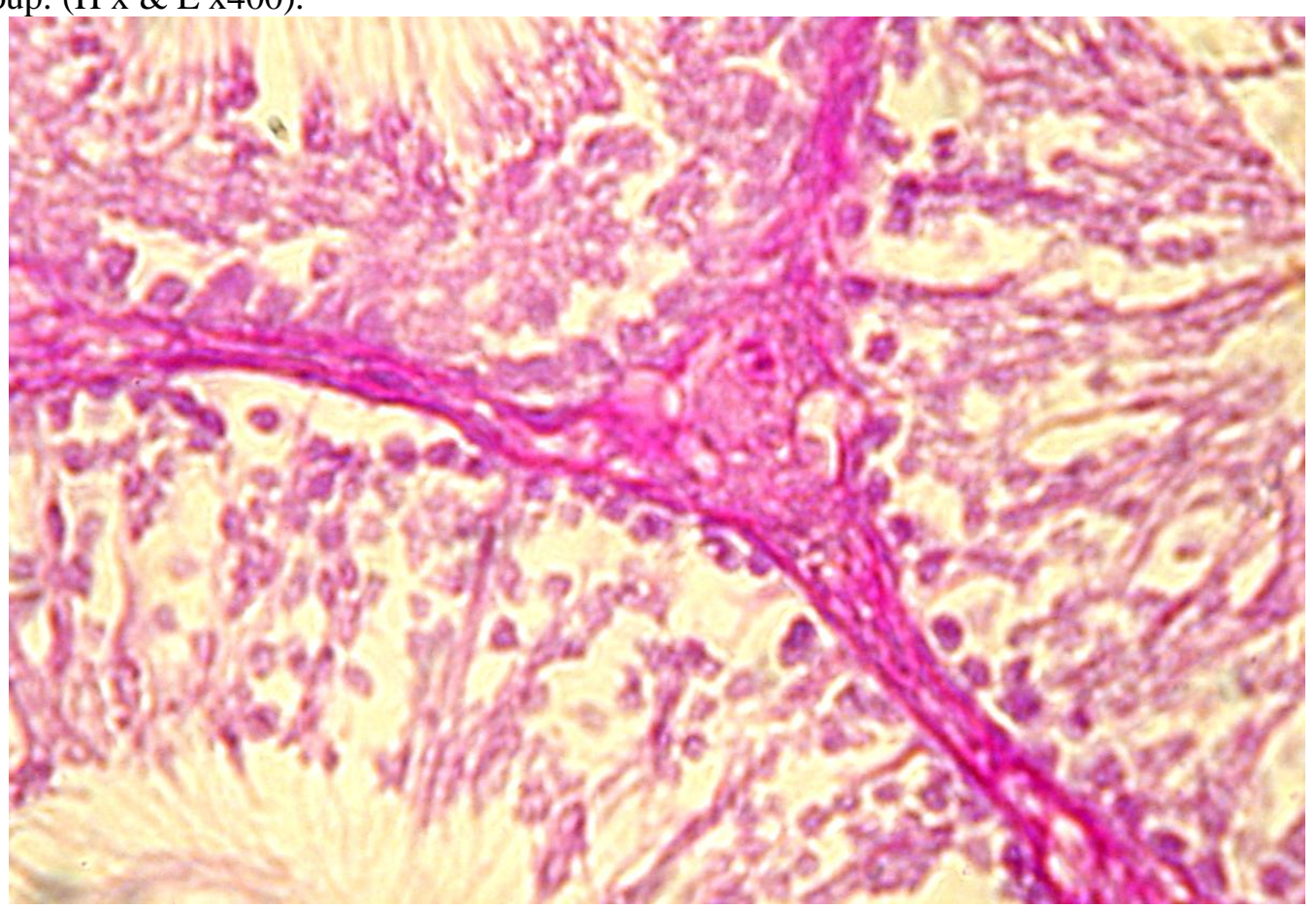

Fig. (20): Photomicrograph of recovery group D rat testis showing modered distribution of PAS +ve materials in the basement membranes of the seminiferous tubules (PAS reaction X 400).

\section{B) Laboratory tests and Statistical analysis}

The testosterone levels increased in the groups submitted to Sildenafil treatment and reached its maximum level in group D senile rats when compared with the control group, but in the recovery groups the testosterone levels where directed toward the normal value especially in recovery rats of group D. 
Table (1): shows testosterone level(ng $/ \mathrm{ml})$ in the control, treated and recovery groups of the senile rats

\begin{tabular}{|l|c|c|c|}
\hline \multicolumn{1}{|c|}{ Groups } & Mean \pm SD & t-test & p-value \\
\hline Control (GA) & $0.39 \pm 0.06$ & & $0.001^{* *}$ \\
\hline Treated (GB) & $0.87 \pm 0.06$ & 12.649 & $0.001^{* *}$ \\
\hline Treated (GC) & $1.44 \pm 0.04$ & 32.559 & $0.001^{* *}$ \\
\hline Treated (GD) & $1.81 \pm 0.05$ & 40.654 & $0.001^{* *}$ \\
\hline Recovery (RB) & $0.73 \pm 0.01$ & 12.499 & $0.001^{* *}$ \\
\hline Recovery (RC) & $1.04 \pm 0.07$ & 15.765 & $0.001^{* *}$ \\
\hline aRecovery (RD) & $1.20 \pm 0.01$ & 29.776 & \\
\hline
\end{tabular}

P-value compared to the control group

P $>$ 0.05: Non significant $\quad$ P $<0.05$ : Significant $\quad P<0.01$ : Highly significant**

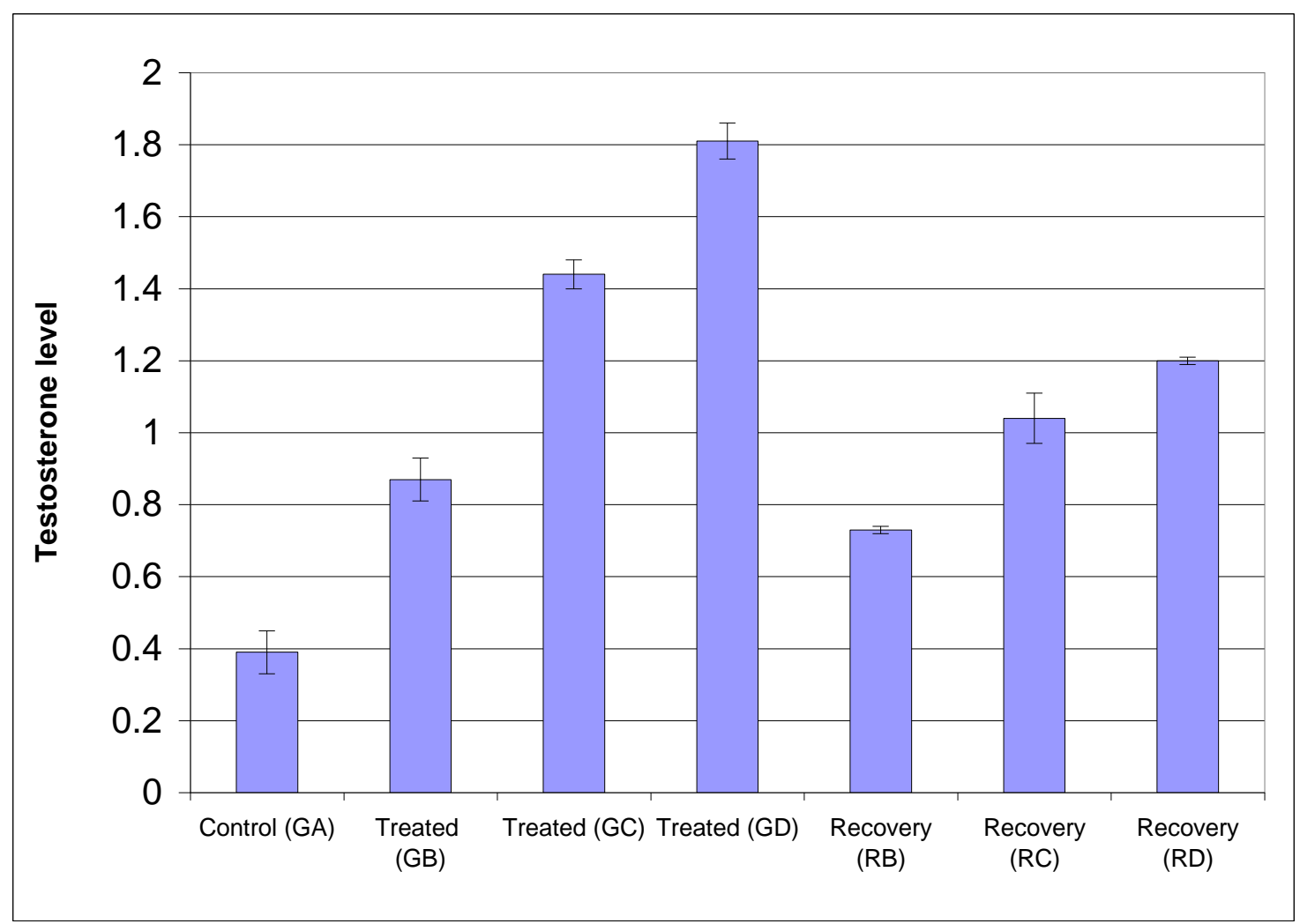

Histogram (1): Showing the mean level of testosterone $(\mathrm{ng} / \mathrm{ml})$ in the control, treated and recovery groups of senile rats.

All the treated and recovery groups (Tab.1\&Hist.1) showed high significant increase $(\mathrm{p}<0.01)$ in testosterone levels when compared with the control group. 
Ezz-Eldin Abdalla et al

Table (2): shows PAS reaction in the control, treated and recovery groups of the senile rats.

\begin{tabular}{|l|c|c|c|}
\hline \multicolumn{1}{|c|}{ Groups } & Mean \pm SD & t-test & p-value \\
\hline Control (GA) & $0.16 \pm 0.05$ & & $0.196^{*}$ \\
\hline Treated (GB) & $0.19 \pm 0.05$ & 1.342 & $0.001^{* *}$ \\
\hline Treated (GC) & $0.25 \pm 0.05$ & 4.025 & $0.01^{* *}$ \\
\hline Treated (GD) & $0.33 \pm 0.05$ & 7.603 & $0.627^{*}$ \\
\hline Recovery (RB) & $0.17 \pm 0.04$ & 0.494 & $0.122^{*}$ \\
\hline Recovery (RC) & $0.20 \pm 0.06$ & 1.620 & $0.001^{* *}$ \\
\hline Recovery (RD) & $0.28 \pm 0.06$ & 4.859 & \\
\hline
\end{tabular}

P-value compared to the control group

P > 0.05: Non significant* $\quad$ P $<0.05$ : Significant $\quad P<0.01$ : Highly significant**

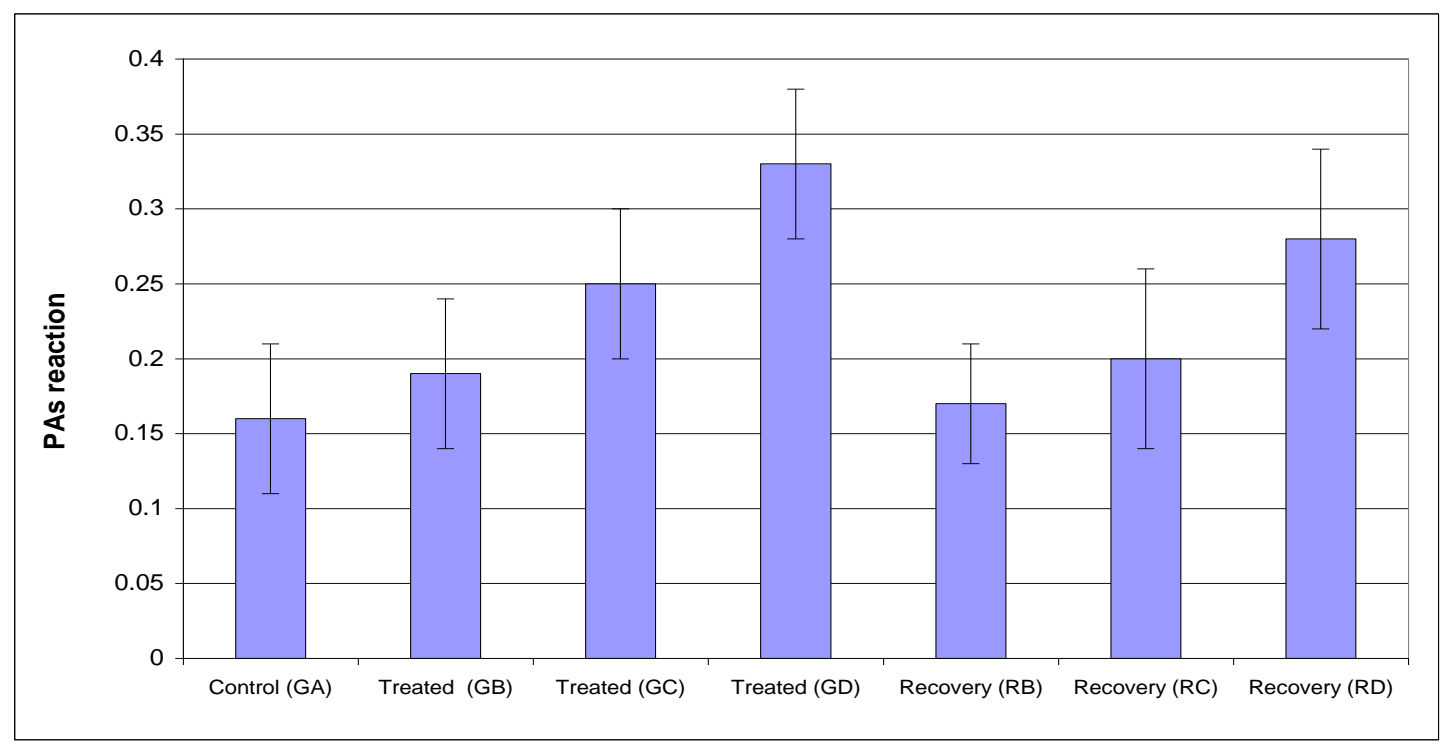

Histogram (2): Showing the MOD values of PAS reaction between the control, treated and recovery groups of the senile rats.

All groups (Tab.2\&Hist.2) showed highly significant increase $(<0.01)$ except group $(\mathrm{GB})$, recovery $(\mathrm{RB})$ and recovery $(\mathrm{RC})$ which showed insignificant increase when compared with the control senile rats.

Table (3): Shows thickness of the basement membranes in the control, treated and recovery groups of the senile rats.

\begin{tabular}{|l|c|c|c|}
\hline \multicolumn{1}{|c|}{ Groups } & Mean \pm SD & t-test & p-value \\
\hline Control (GA) & $6.11 \pm 0.94$ & & $0.042^{*}$ \\
\hline Treated (GB) & $7.24 \pm 1.34$ & 2.183 & $0.001^{* *}$ \\
\hline Treated (GC) & $9.29 \pm 1.47$ & 5.763 & $0.001^{* *}$ \\
\hline Treated (GD) & $14.02 \pm 1.66$ & 13.112 & 0.051 \\
\hline Recovery (RB) & $7.12 \pm 1.21$ & 2.084 & $0.001^{* *}$ \\
\hline Recovery (RC) & $8.12 \pm 1.16$ & 4.257 & $0.001^{* *}$ \\
\hline Recovery (RD) & $11.88 \pm 1.19$ & 12.032 & \\
\hline
\end{tabular}

P-value compared to the control group

P $>0.05$ : Non significant $\quad P<0.05$ : Significant $* \quad P<0.01$ : Highly significant** 


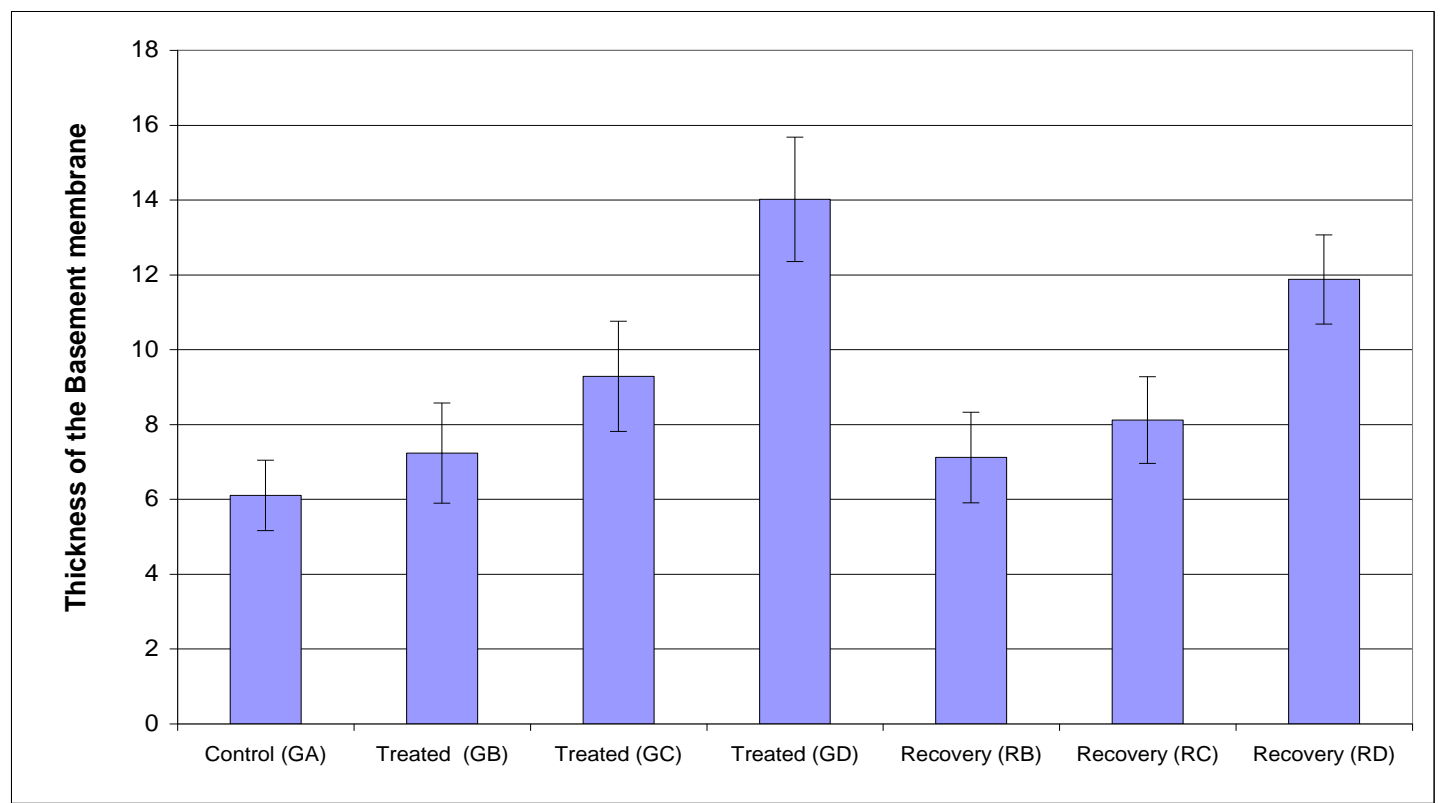

Histogram (3): Showing the mean of the thickness of the basement membrane in the control, treated and recovery groups of the senile rats.

All groups (Tab.3\&Hist.3) showed highly significant increase $(<0.01)$ in thickness of the basement membranes, when compared with the control group, except recovery (RB) showed a borderline significant

\section{DISCUSSION}

Everyone has no doubt heard about the new "wonder drug" for impotency. Taken an hour before anticipated sexual activity it has a 40 to $70 \%$ success rate. Taken with organic nitrates, Viagra can seriously endanger or take life (Hemophilia, 1998).

Erectile dysfunction (ED) is a common condition that may result from psychological, neurologic, hormonal, arterial or cavernosal impairment, or from a combination of these factors (Aversa and Fabbri, 2001).

After oral therapy, Sildenafil circulates in plasma at micro molar concentration which can cause a minor inhibition of PDE which determine transient side effects ( Jackson, 1999).

The side effects of sildenafil citrate are mostly mild to moderate. They usually go away after a few hours. Some of these are more likely to happen with higher doses, producing headache, feeling flushed, upset stomach, eye being more sensitive to light or blurred vision (Pfizer, 1998; Mendelsshon, 2005).

To our knowledge, there have been few reports of the histological effects of Viagra on the testicular structure and the level of testosterone hormone. In the present work, we investigated the effect of 
administration recovery group of the present study was used to detect if the changes in the testis and testosterone levels were reversible or irreversible.

In the present study, there were numerous histological changes in the different groups appeared with change the dose of the drug and period of administration, this led to impaired spermatogenesis, in the form of decreased cells of the spermatogenic layers ,detached germ cells and arrested spermatogensis at the level of primary spermatocytes and necrosis of the seminiferous tubules, also we detected highly significant increase in the thickness of the basement membranes widened interstitial tissues with deposition of acidophilic materials. Also, congested and dilated blood vessels with increased number of Leydig cells were also realized. PAS reaction showed highly significant increase in between the different groups. These changes were reversible in recovery groups.

In this respect, Gumuş et al. (2004) found abnormalities in the testis of rat due to increased dose of sildenafil.

Tuorkey and Abdul Aziz (2012)

found that increased dose of Sildenafil Citrate depressed both spermatogenesis and spermiogenesis.
Al-fartosi (2009) investigated the effect of long term administration of Sildenafil Citrate on sperm count, sperm malformations and testicular histological changes of male rats. The histological changes observed by this author are in agreement with the results of the present study,since necrosis of somniferous tubules, destruction of cells of the spermatogenic layers , impaired spermatogenesis, arrested spermatogenesis at level of $1^{\mathrm{ry}}$ spermatocytes and disruption of the epithelial lining of the seminiferous tubules were detected. These effects may be according to the changes in the expression of various receptors associated cGMP or responsive effect of these reseptors in the brain and this will cause damage of testicular tissues and failure in spermatogenesis (Canteros, 1998; Tocharus, 2005).

Yoshida et al. (2007) and Schell et al. (2010) reported that morphological alterations of the basement membrane are generally accepted to be associated with impaired spermatogenesis. Thickening of the basement membrane o the seminiferous tubules describes accumulation of collagen fibers and further extracellular components, which are referred to as fibrosis and well described in other organs, e.g. the lung, liver, heart and kidney ( Dempsey et al., 2006; Rosenbloom et al., 2010) that was observed in the present study. 
Leblond and Clermont (1952) found that in the adult rat testis, there is a moderate PAS reaction in the basement membrane of seminiferous tubules and collagen stroma. The reaction is faint in the interstitial cells and nearly absent from other elements of the testis. Also Fabbrini et al. (1969) showed that the PAS positive materials which are found in the human testis is mainly glycogen.

In this study, normal magenta red colour of PAS (+ve) materials in control group was detected in the basement membranes of seminiferous tubules, spermatogonia and in the interstitial tissue. Altered PAS stain affinity was observed in present study in different groups. This means that the mucopolysaccharides content was affected probably with the presence of changes either in the spermatogenic cells or in the basement membranes.

Govender et al. (2004) reported that the glycogen content in the seminiferous tubules give the energy requirement which may be changed with damage or alternation in structure of seminiferous tubules.

Andric et al. (2007) reported that a little is known on the action of sildenafil on cGMP/cAMP signaling and testicular steroidogenesis

Glenn et al. (2007) reported that the PDE5 inhibitors promote their pharmacological effects by inhibiting phosphodiesterase type 5, an enzyme responsible for the degradation of cGMP. The raised levels of this cyclic nucleotide affect many intracellular functions. This drug mechanism could be involved in the activation of the steroidogenic pathway and testosterone secretion, since,PDE5 was identified in Leydig cells( Scipioni $\boldsymbol{e t}$ al., 2005).

The present work showed that at level of hormonal assay there was highly significant increase of serum testosterone in the different treated groups especially in group $\mathrm{D}$, but in recovery groups tend to be reversible condition.

A similar effect was reported with two different types of PDE5 inhibitors (sildenafil and tadalafil) applied to men who suffered from erectile dysfunction ( Carosa et al., 2004).

Middendorff et al. (2000) suggests that cGMP pathways have been described to modulate testosterone secretion.

Karina et al. (2009) reported that the treatment with Sildenafil increased the testosterone biosynthesis in Leydig cells, probably through cGMP accumulation due to PDE5 inhibition.

Silvana et al. (2010) suggested that prolonged Sildenafil treatment in vivo stimulated Leydig cells steroidogenesis 
and increased circulating level of testosterone due to coordinative stimulatory effect of cAMP and cGMP action

In conclusion: use of sildenafil citrate led to some morphological changes in testicular structure and also increased the testosterone level. So we advice to limit the wide use of sildenafil by different age categories. Also another researches are needed to detect the side effects of sildenafil.

\section{REFERENCES}

Abbott D, Comby P and Charuel C (2004): Preclinical safety profile of Sildenafil. Int. J. Impot. Res., 16:498-504.

- Al-fartosi K (2009): Effects of long term administration of sildenafil citrate (viagra) on some sperm characteristics and testis architecture on male rate. Bas. J. Vet. Res., 8 (2): 91-103.

- Altman DG (1991): Practical Statistics for Medical Research. Chapman and Hall: London.

Andric SA, Janjic MM, Stojkov NJ and Kostic TS (2007): Testosterone-induced modulation of nitric oxide-cGMP signaling pathway and androgenesis in the rat Leydig cells. Biol. Reprod. Doi.,10.1095-1105.

Aversa A and Fabbri A (2001): New oral agents for erectile dysfunction: what is changing in our practice. Asian J. Androl., 3:175-179.

Boolell M, Allen MJ and Ballard SA (1996): Sildenafil an orally active type 5 cyclic GMP-specific phosphodiesterase inhibitor for the treatment of penile erectile dysfunction. Int. J. Impot. Res., 8:47-52.

Burnett A L (1995): Role of nitric oxide in the physiology of erection. Biol. Reprod., 52: 485-489.

Canteros G (1998): Nitric oxide synthase content of hypothalamic explants: Increase by nor epinephrine and activated by $\mathrm{NO}$ and CGMP. Proceeding of Natural Academy of Science, USA., 93:4246-4250.

Carosa E, Martini P, Brandetti F, Di Stasi SM, Lombardo F, Lenzi A and Jannini
EA (2004): Type V phosphodiesterase inhibitor treatments for erectile dysfunction increase testosterone levels. Clin .Endocrinol. (Oxf)., 61: 382-386.

Corbin JD and Francis SH (1999): Cyclic GMP. Phosphodiesterase-5: target of sildenafil. J. Biol. Chem., 274: 13729-13732.

Dempsey OJ, Kerr KM, Gomersall L, Remmen $H$ and Currie GP (2006): Idiopathic pulmonary fibrosis: an update. QJM ,99:643-654

Drury RA and Wallington EA (1980): Carleton's Histological Technique" $5^{\text {th }}$ Edition .Oxford Univ. press. London, New York, Toronto.

Eardley I (2001): Efficacy and safety of sildenafil citrate in the treatment of men with mild to moderate erectile dysfunction The British Journal of Psychiatry, 178: 325-330.

-Fabbrini A, Re $M$ and Conti C (1969): Glycogen in the normal human testis: A histochemical and histoenzymatic study. J. Endocrinol., 43: 499-506.

- Feldman HA, Goldstein I, Hatzichristou DG, Krane RJ, McKinlay JB (1994): Impotence and its medical and psychosocial correlates: results of the Massachusetts Male Aging Study. J Urol., 151: 54-61.

- Glenn DRJ, McVicar CM, MecClure N and Lewis SEM (2007): Sildenafil citrate improves sperm motility but causes a premature acrosome reaction in vitro. Fertil. Steril., 87:1064-1070.

- Govender D, Sing Y and Chetty R (2004): Sertoli cell nodules in the undescended testis: a histochemical, immunohistochemical, and ultrastructural study of hyaline deposits. Department of Pathology, Nelson R Mandela School of Medicine, University of Natal, Private, Congella, Durban, 4013.

- Gumus B, Vatansever HS, Müezzinoglu T, Müftüoglu S and Kaymaz F (2004): Histopathological effects of sildenafil citrate on rat corpus cavernosum. Acta. Histochemica., 106: 37-45.

- Hemophilia OS (1998): Viagra proceed with cautions Associated histological deterioration. Reuters Health Information Service.

- Jackson G (1999) : Sildenafil (Viagra) and ophthalmology. Sur. Ophthalmic, 44 : 153162.

Jarrar BM (2011): Histological alterations in the testicular tissue induced by sildenafil overdoses. Bentham Science Publishers Ltd. $., 5(2): 99-103$

Kalsi JS and Kell PD (2004).Update on oral treatments for male erectile 
dysfunction.J.Eur.Acad.Dermatol.Venereol.,18 :267-274 .

- Karina LAS, Amanda K, Maria I W, Araken A, José R B and Christina A P (2009): Chronic treatment with sildenafil stimulates Leydig cell and testosterone secretion. int J Exp Pathol., 90(4): 454-462.

- Kloner $R$ and Zusman $R$ (1999): Cardiovascular effects of sildenafil citrate and recommendations for its use. Am. J. Cardiol., 84: 11-17.

- Leblond CP and Clermont Y (1952): Definition of the stages of the cycle of the seminiferous epithelium in the rat. Ann. N. Y. Ac.Sci.,55:548-573.

- McMahon CG, Samali $R$ and Johnson H (2000): Efficacy, safety and patient acceptance of sildenafil citrate as treatment for erectile dysfunction. J. Urol., 164: 1192-1196.

- Mendelsshon M (2005) : Viagra now mending hearts. Nat. Med., 11:115-116.

- Michel T (2006): Treatment of myocardial ischemia. In: The Pharmacological Basis of Therapeutics. Goodman and Gilman's, $11^{\text {th }}$ ed.London.

- Middendorff R, Davidoff MS, Behrends S, Mewe M, Mietens A and Müller D (2000): Multiple roles of the messenger molecule cGMP in testicular function. Andrologia , 32:55-59.

- Mizusawa H, Hedlund P, Hakansson A, Alm $P$ and Andersson $\mathbf{K} \quad \mathbf{E}$ (2001): Morphological and functional in vitro and in vivo characterization of the mouse corpus cavernosum. Br. J. Pharmacol., 132: 1333-1341.

- Paget GE and Barnes JM (1964): Evaluation of drug activities, In: Pharmacometrics. Lawrence DR and Bacharach AL, editors, New York :Academic press., Vol.1. Pp. 161.

- Pearse A (1977): Histochemistry ,Theoretical and Applied $.3^{\text {rd }}$ ed,.Vol.1. Churchill Livingstone. London.

- Pfizer (1998): Pfizer labs. Division of Pfizer mc, NY, NY 100017, printed in USA., 695485-00-2.
Rosen RC (2001): Psychogenic erectile dysfunction. Classification and management. Urol. Clin. North Am., 28: 269-278.

- Rosenbloom J, Castro SV and Jimenez SA (2010): Narrative review fibrotic diseases: cellular and molecular mechanisms and novel therapies. Ann. Intern. Med.,152:159-166.

- Schell C, Albrecht M, Spillner S, Mayer C, Kunz L, Köhn FM, Schwarzer $U$ and Mayerhofer A (2010): 15-Deoxy-delta 12-14prostaglandin-J2 induces hypertrophy and loss of contractility in human testicular peritubular cells: implications for human male fertility. Endocrinology ,151:1257-1268.

- Scipioni A, Stefanini S, Santone $\mathbf{R}$ and Giorgi M (2005): Immunohistochemical localization of PDE5 in Leydig and myoid cells of prepuberal and adult rat testis. Histochem. Cell Biol.,124:401-407.

- Silvana Andric A, Marija Janjic M, Natasa Stojkov J and Tatjana Kostic S (2010): Sildenafil treatment in vivo stimulates Leydig cell steroidogenesis via the cAMP/cGMP signaling pathway Am. J. Physiol. Endocrinol. Metab ., 299:544-550.

- Tocharne C (2005) : Effect of long - term treatment of Butea superba on sperm motility and concentration. Naresuan University Journal, 13 (2) : 11-17.

- Tuorkey M and Abdul Aziz K (2012): Effects of sex enhancing drugs on different organs in male Swiss Albino Mice: Values of Safety, Scientific Reports, 1:133-145.

Uthayathas S, Karuppagounder SS, Thrash B M, Parameshwaran K, Suppiramaniam V and Dhanasekaran M (2007): Versatile effects of sildenafil: recentpharmacological applications. Pharmacol. Report, 59: 150-163.

Yoshida S, Sukeno $M$ and Nabeshima Y (2007): A vasculatureassociated niche for undifferentiated spermatogonia in the mouse testis. Science, 317:1722-1726.

- Zar JHS (1996): Biostatistical Analysis. $3^{\text {rd }}$ ed. Upper Saddle River, NJ: Prentice-Hall.London 


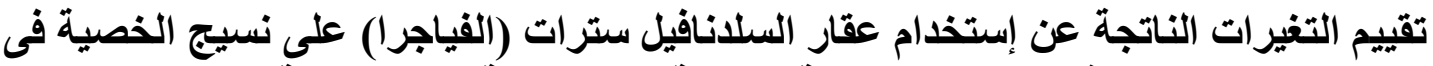
الجرذان البيضاء المسنة (دراسة هستولوجية ولئة وكميا حيوية)

\section{عزالدين الشرقاوي عبد الله- زينب محمود جبالي ـعبد الغني عبد الجواد مصطفي-ابراهيم محروس عمرو}

من كلية الطب بنين بدمياط - و كلية الطب بروب بنات بالقاهرة

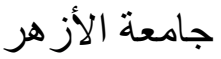

يعد عقار السلدنافيل سترات من أول و أكثر المستحضر ات الطبية المستخدمة فى علاج ضعف الاتتصـاب عند الرجال, وقد أظهرت بعض الدراسات الأعر اض الجانبية لهذا العقار , تهدف هذه الدراسة لتقيم تأثير العقار على أنسجة الخصية فى الجرذان البيضاء المسنة.

في هذه الدر اسة تم إستخدام 40 من ذكور الجرذان البيضاء المسنة والتي يترواح وزنها مـا بين 250 الي 300 جر ام وقد تم تقسيمها إلى 4 مجموعات متساوية , اعتبرت المجموعة الأولي هى المجموعة الضـابطة ,و المجموعة الثانية

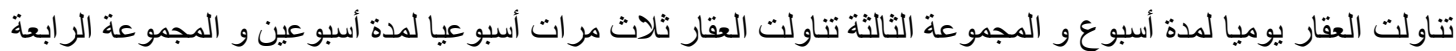
تناولت العقار أسبو عبا لمدة أربعة أسابيع وقد تم تقسيم الجرذان فى الثلاث مجموعات الأخيرة بحيث أنه تم ترك نصفيا بدون علاج لفترة أسبو عين بعد نوقف تتاول العقار وذلك لتقيم ما إذا كان تأثئر الدو اء دائم أم بمكن أن تعود الأنسجة إلي

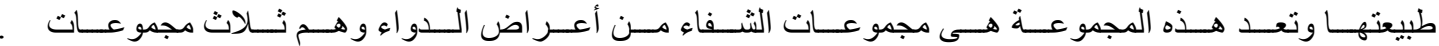

الجر عة المستخدمة فى هذه الدر اسـة هى 1.5 مل جر ام/جرذ مذاب في 1.5 مل مـاء وتم إعطاؤهـا باستخدام

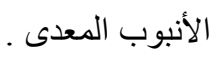

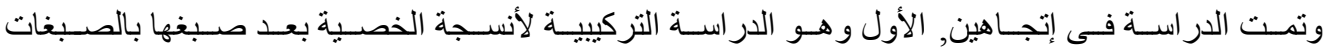

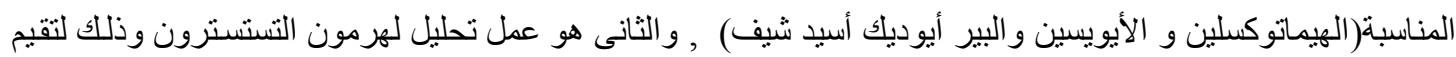
مدى التأثير الناتج من إستخدام العقار.

وقد دلت النتائج على مدى تأثر أنسجة الخصية فى المجموعات الدختلفة إلي حد توقف عملية إنتاج الحيوانات المنوية فى المجموعة الر ابعة وكذا زيادة نسبة هرمون التستسترون من مجموعة إلى أخرى, وقد أظهرت النتائج فى المجموعة الخامسة أن تأثير العقار مرتجع وليس دائم وقد ظهر ذلك بوضوح من تحسن انسجة الخصبة من مجموعة إلي أخري.

ويستتج من هذة الدراسة مدى نأثير إستخدام عقار السلدنافيل سترات (الفياجر )على أنسجة الخصية ومستوى

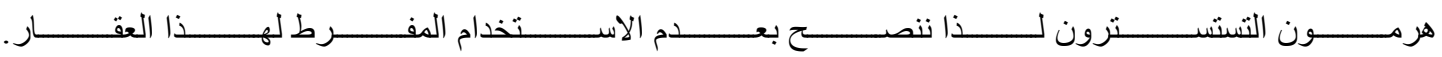

